\title{
Joint Ventures em ambientes frágeis O caso do alumínio na Amazônia
}

\section{Stephen Bunker}

Professor do Departamento de Sociologia da

Universidade de Wisconsin - Madison.

\section{Resumo}

Ao examinar as mudanças no mercado mundial de alumínio, este artigo analisa as estratégias japoneses para assegurar o acesso a este metal, os efeitos de sua exploração na Amazônia brasileira e suas conseqüências para as indústrias de alumínio no mundo.

Examina como as características físicas e ambientais do alumínio e dos lugares de ocorrência deste minério tornam sua extração lucrativa e sua exportação competitiva. Discute ainda que a competição entre consumidores centrais tem tido como resultado o enfraquecimento da posição dos países periféricos exportadores de matériasprimas.

\section{Palavras-Chave}

Amazônia - Alumínio - Mercado Internacional - Extrativismo - Mineral

\section{Abstract}

By examining the recent changes in the aluminum world trade structure this article emphasizes the Japanese strategies to secure the access to this metal, the effects of such strategies on the Brazilian Amazon region, and their consequences for the world aluminum industry. It examines how the specific environmental and physical characteristics of the aluminum and of the sites its exploitation influence its profitability and turns competitive its exportation. It discusses also that competition between core consumers has resulted in the weakening in the position of the peripheral exporters of raw materials.

\section{Keywords}

Amazon - Aluminum - World Trade Mineral 


\section{Introdução}

Os preços das matérias-primas determinam as taxas de lucro, a composição orgânica e as taxas de circulação e acumulação de capital (Marx, 1967, vol. III). A falta de matérias-primas desestabiliza as economias, provocando desemprego, causando a inflação, criando problemas de afunilamento nas indústrias interligadas, além de ameaçar as instituições financeiras com inadimplências e falências. Portanto, em nações industrializadas, tanto o Estado quanto as empresas agem de forma estratégica para assegurar fluxos contínuos de matérias-primas baratas, particularmente daquelas que abastecem setores da economia nacional em que os recentes avanços tecnológicos criaram oportunidades para lucros excedentes ou requisitos para a defesa nacional (Marx, 1967; Lenin, 1939; Krasner, 1976; Keohane, 1984; Vernon, 1983; Brockway, 1979; Moran, 1987 - embora abordem esse fenômeno a partir de uma grande variedade de perspectivas teóricas, todos esses autores o documentam). As estratégias bem-sucedidas podem cristalizar-se em mercados estáveis de matérias-primas, dominados, sustentados e regulados por poucas empresas e ainda por um número reduzido de Estados (McMichael, 1984; Friedmann, 1992). Essas empresas e Estados geralmente organizam os mercados em que atuam considerando suas próprias vantagens corporativas e nacionais. Os Estados e empresas nacionais, que aspiram a subir na hierarquia do sistema mundial de economias nacionais, provavelmente temem que regimes estabelecidos de mercado os deixem vulneráveis à escassez periódica e a preços mais altos. Eles tendem, portanto, a projetar estratégias particularmente agressivas para superar o domínio de mercados estabelecidos. Entendo que tais nações ou hegemonias em ascensão (cf. Chase-Dunn, 1989), ao projetar suas estratégias, devem estar particularmente atentas para as características físicas de recursos naturais específicos e tensões entre nações periféricas exportadoras e nações centrais importadoras.

Apesar da grande importância das matérias-primas para a produção industrial, as economias especializadas em exportá-las têm sido tipicamente menos desenvolvidas, menos estáveis e mais sujeitas às condições declinantes de comércio do que as economias industrializadas que dependem delas. Essas desvantagens podem tornar-se mais agudas durante períodos de expansão econômica mundial. Isto é paradoxal, pois seria de esperar que o aumento da demanda por matérias-primas fortalecesse a posição negociadora de economias extrativas (Bairoch, 1986: 206-207). Estratégias competitivas e agressivas entre as nações mais poderosas, porém, podem induzi-las a usar meios extra-econômicos para subordinar nações periféricas fornecedoras de recursos e, se possível, a transferir para elas os custos extras dessas estratégias.

Subjacentes a esse paradoxo, há duas tensões ou contradições fundamentais na interação entre economia e ecologia. A primeira contradição é que o aumento da produtividade do trabalho e do capital requer uma expan- 
são da oferta e uma qualidade mais alta de matérias-primas, mas isso só é possível, com o passar do tempo, se fontes mais distantes forem exploradas para compensar a diminuição dos recursos das fontes mais próximas. Isso aumenta os custos de transporte como também ameaça as nações competidoras com a interdição e a restrição das ofertas. A manutenção dessa ameaça dentro de limites toleráveis pode impor custos significativos tanto para os Estados quanto para as empresas. Portanto, os recursos naturais contribuem para o aumento da produtividade e para a redução de seus custos, mas o custo de assegurar o acesso a eles pode obter substancialmente sua contribuição para a produtividade e os lucros. Uma economia ascendente, tentando competir em mercados industriais mundiais, deve equilibrar suas necessidades de acesso a matérias-primas baratas e de alta qualidade com os custos extra-econômicos que a garantia de acesso normalmente requer. A segunda contradição emerge da primeira. As estratégias de Estados e empresas são potencialmente bastante flexíveis no sentido de que diferentes arranjos corporativos, de propriedades, monetários e políticos podem ser criados por meio de acordos, ou impostos por meio de conflitos sociais. A natureza, por outro lado, é bastante rígida na localização de recursos naturais, na qualidade dos depósitos e nas propriedades físicas dos recursos e do ecossistema em que estão localizados. A ausência de competição extra-econômica entre empresas e Estados, decisões sobre a localização e a taxa de extração e processamento refletiriam na qualidade e no tamanho dos depósitos e suas distâncias, ou nos custos de transporte, para os mercados. Tanto a teoria ricardiana sobre a renda, quanto a teoria da vantagem comparativa baseiam-se nessas suposições. De fato, como David Harvey (1982) assinala, a renda diferencial racionaliza a distribuição e o uso de recursos naturais. Nesse sentido, a lógica de redução do custo competitivo na produção industrial subordina estratégias econômicas e políticas, flexíveis ou voluntárias, à rigidez de propriedades e processos naturais, mas a lógica de assegurar o acesso pode impedir empresas e Estados de adaptarem-se a essas propriedades físicas de modo mais produtivo ou com custo mais efetivo.

Sob um regime de comércio completamente livre, a localização da extração e do processamento seria determinada por custos diferenciais. Há algumas evidências de que, depois que um regime de mercado estável se estabelece, as empresas tendem a apoiar suas decisões locacionais em vantagens naturais a fim de reduzir custos. Como Barham sugere (1994), as empresas podem também manipular vantagens naturais para intimidar concorrentes, mantendo como reservas estratégicas as localidades com custos e depósitos mais atraentes. Porém, numa economia crescentemente competitiva ou crescente, o Estado e as empresas somente podem sentir-se seguros se conseguirem reorganizar os mercados tendo em vista suas próprias vantagens. Se o acordo antigo tornou-se ecologicamente mais eficaz, os desafios vencidos pelas economias desenvolvidas podem ocasionar custos significa- 
tivos, simplesmente porque essas economias terão que buscar novos - porém, normalmente menos eficazes ecologicamente - acordos de mercado, baseados em diferentes condições locais de extração e processamento. Porque a economia desenvolvida - para ser industrialmente competitiva - não poderá assumir os custos extras desse comportamento estratégico, as empresas e Estados tentarão transferir alguns desses custos para as nações exportadoras. Desse modo, emerge a hipótese paradoxal de que a competição entre consumidores de países centrais pode realmente debilitar a posição dos exportadores periféricos de matérias-primas.

Em resumo, estratégias bem-sucedidas de acesso a recursos transgridem a soberania das nações e os interesses econômicos e ambientais das comunidades de cujos territórios essas matérias-primas são extraídas. As estratégias que visam à garantia de acesso para o consumidor industrial necessariamente subordinam as considerações de racionalidade econômica e proteção ambiental do empreendimento de extração ou da região onde o(s) recurso(s) é(são) extraído(s). Na medida do possível, os Estados centrais e as empresas transferem esses custos para os Estados ou regiões de economias exportadoras de matérias-primas.

A competição entre economias nacionais, que ocasiona mudanças na hierarquia do sistema mundial, exacerba esses efeitos. Neste artigo examino a hipótese (1) de que o comportamento estratégico de Estados e empresas para garantir o acesso a matérias-primas diminui a eficiência econômica e ecológica e o retorno de benefícios na extração de recursos naturais, e (2) de que esse comportamento estratégico e seus efeitos são intensificados durante mudanças na hierarquia do sistema mundial. Dada a complexidade tanto dos processos econômico-políticos quanto dos processos ecológicos envolvidos, e limitando-me ao (recurso) alumínio, optei por considerar as estratégias da mais recente e efetiva economia competidora, o Japão, e seus efeitos sobre um único país, o Brasil.

Desde 1960, a ascendência japonesa no sistema mundial transformou aquela nação no maior importador mundial de matérias-primas e impulsionou empresas e Estado japoneses vir a procurar ofertas estáveis e baratas de todos os minerais importantes. O Brasil tornou-se um fornecedor importante de minerais para o Japão. Examino as estratégias japonesas para garantir fontes de alumínio, seus efeitos sobre as regiões e nações exportadoras dessa matéria-prima semi-elaborada, e suas conseqüências para a indústria mundial de alumínio. Faço isso enfocando primeiramente as estratégias de obtenção e de consumo das nações importadoras e empresas industriais, e depois discuto a operação e os efeitos da estratégia japonesa no Brasil. A fim de separar fenômenos conjunturais e de mercadorias (commodities) específicos de estruturas e processos comuns ao fluxo de todas as matérias-primas de economias extrativas para economias produtivas, faço referência comparativa às estratégias de matérias-primas de hegemonias crescentes em outras épocas. 
O leitor deverá seguir quatro diferentes tipos de processo, que convergem para um único caso. O primeiro tem a ver com mudanças específicas na organização da indústria internacional do alumínio. Enquanto a escala de capital adequada à eficiência ótima em mineração, refino, fundição e transporte tem aumentado, também aumentou a difusão espacial de minas, fundições e instalações de produção final. O segundo mostra como as características ambientais e físicas específicas do alumínio e dos locais que permitem sua extração e processamento lucrativo constrangeram o Brasil e outras nações exportadoras de alumínio, e influenciaram estratégias hegemônicas. O terceiro tem a ver com a hierarquia alterada da economia mundial desde 1960, quando o Japão e a Alemanha se deslocaram para posições dominantes e nações ricas em recursos naturais lutaram para obter maior vantagem das matérias-primas que exportam. Esses dois processos contribuíram, entre outras coisas, tanto para um enorme excedente financeiro e um crédito fácil nos meados de 1970, como para os altos níveis da dívida dos países de Terceiro Mundo, na década de 80. O quarto envolve os modos como os japoneses amoldaram as estratégias tanto para reduzir o risco quanto para explorar as vantagens que os dois primeiros processos representaram para eles, enquanto tentavam livrar o próprio fornecimento de alumínio do controle dos oligopólios estabelecidos na Europa e nos EUA durante a primeira metade do século XX. Essas estratégias não só garantiram que o Japão contasse com fontes seguras e baratas de alumínio, mas contribuíram também, de muitas formas, para mudanças fundamentais na estrutura do comércio mundial desse metal, muitas vezes em detrimento dos países ricos em recursos naturais, que os japoneses induziram a parcerias colaboradoras na redução eletrolítica do alumínio.

\section{Alumínio: crescimento e realocação}

O consumo global de alumínio excedeu o crescimento de qualquer outro mineral importante neste século. Sua estrutura molecular, que o torna leve e forte, além de permitir sua amalgamação com uma variedade excepcionalmente grande de outros metais, tornou-o particularmente apto para a incorporação nas novas tecnologias de transporte e construção, que caracterizaram os setores dominantes durante este século. O alumínio resiste ao processo de ferrugem e conduz eletricidade, competindo assim, fortemente, com o cobre e o estanho nos mercados de rápida expansão, que foram dominados por esses metais mais antigos. Sua redução por meio de eletrólise consome mais energia que qualquer outro metal primário. Mas, mesmo representando 40 a 50 \% dos custos de processamento, a energia era suficientemente barata durante os primeiros 80 anos da indústria, quando o alumínio era normalmente vendido por menos do que o cobre.

Os custos e os preços subiram rapidamente após 1973, mas a urgência em substituir metais pesados por metais leves, quando os preços do petróleo aumentaram, fez crescer a demanda ainda mais rapidamente. Os choques do 
petróleo, em 1973 e 1979, tiveram, entretanto, efeitos profundos na estrutura financeira, energética, de mercado, de propriedade e espacial da indústria. Custos de produção crescentes, novas economias de escala - que aumentaram imensamente o investimento por indústria -, instabilidade de preços, demanda expandida e o surgimento do nacionalismo em relação aos recursos de muitas nações pobres, porém, ricas em minerais, reduziram a capacidade e a vontade dos seis maiores e mais importantes produtores, todos situados na Europa e na América do Norte, de continuarem dominando as fontes, regulando ofertas e conduzindo mercados. O alto preço do petróleo favoreceu a transferência de usinas de alumínio para áreas distantes com grande potencial hidrelétrico. A maioria desses lugares ou não era desenvolvida ou simplesmente não estavam conectadas às nações industriais do centro. O aumento da resistência popular em relação à poluição industrial também ameaçou a elevação do custo de novas instalações nos países desenvolvidos.

O Japão, com um pequeno potencial hidrelétrico, ainda inexplorado, e confrontado com uma preocupação popular crescente sobre a qualidade ambiental das ilhas, já havia iniciado a procura por fontes externas seguras de alumínio, antes de 1973. O refino e a redução doméstica do minério expandiram rapidamente na década de 60, mas ainda estava abaixo do consumo japonês de alumínio primário. O custo interno do alumínio era mais alto que o custo do mercado internacional. Assim, mesmo antes dos rápidos aumentos no custo de energia gerada de forma térmica, que, em última instância, levaram ao fechamento da maioria das usinas de alumínio do Japão, uma livre aliança de empresas, federações empresariais e agências do governo procurava caminhos para aumentar as importações de bauxita e alumina, com base em contratos de longo prazo na Austrália, e do alumínio, em uma parceria na Nova Zelândia.

A maioria dos depósitos de bauxita tri-hidratada, suficientemente grandes para sustentar o atual nível necessário para a extração, estavam localizados nos trópicos. O entusiasmo de muitas nações tropicais para desenvolver indústrias com efeitos (linkages) para trás em relação a seus próprios minerais, a equação convencional de energia elétrica com efeitos para frente em direção às indústrias tecnologicamente avançadas e a dependência da hidroeletricidade, com um alto e confiável índice pluviométrico, em grandes bacias de drenagem, junto com a vasta oferta de renda excedente que as nações exportadoras de petróleo depositaram no sistema bancário das nações centrais, criaram uma ruptura na estrutura estabelecida da indústria global que os japoneses podiam explorar.

Os japoneses estavam dispostos a uma ação agressiva a fim de captar mercados de matérias-primas. Eles estavam transformando sua economia para exportações industrializadas, tecnicamente mais complexas e intensivas no uso de metal. Eles já haviam utilizado contratos de longo prazo, concessões diretas para infra-estrutura e exploração e concedido empréstimos 
para estimular o desenvolvimento das minas de ferro e cobre, dependentes das exportações para o Japão. Seu consumo de alumínio crescia mais rápido do que o de qualquer outra nação e eles tinham sido surpreendidos por várias ameaças de escassez de matérias-primas básicas. O embargo norteamericano da soja, em 1972, indicou dramaticamente para os japoneses que eles não podiam mais contar com os EUA para garantir o fornecimento das matérias-primas necessárias ao desenvolvimento econômico. Os movimentos japoneses anteriores para garantir o fornecimento de cobre e de ferro tiveram a proteção e o apoio implícito dos Estados Unidos. Porém, quando os japoneses começaram a garantir o próprio fornecimento do alumínio, o apoio dos EUA foi condicionado pela crescente percepção do Japão mais como um competidor do que como um importante dependente. Os efeitos de todas essas ameaças ao fornecimento futuro eram exacerbados pelo fato de que a indústria mundial do alumínio era mais controlada do que haviam sido a do ferro e a do cobre. Isso fez com que a hegemonia estabelecida ficasse simultaneamente mais ameaçadora para garantir o acesso e mais difícil de quebrar. Esses problemas eram compostos pela necessidade percebida de transferir a redução e transformação do alumínio, com seus custos de capital muito alto, para fora do Japão. O ferro e o cobre de minas coligadas vinham para o Japão, principalmente como minério. A instalação de usinas de alumínio distantes, caras, e tecnicamente exigentes criou problemas mais complexos do que os antigos artifícios japoneses para assegurar o acesso ao cobre e ao ferro.

Os japoneses resolveram esses problemas da usina procurando parcerias em países com reservas de bauxita e/ou grande potencial hidrelétrico, que tinham também um desenvolvimento industrial suficiente e uma certa facilidade de acesso ao crédito para investir e administrar as operações de usina. Não fizeram nenhuma tentativa para induzir a Guiné, um país muito pobre, com grandes reservas de bauxita, a uma parceria, mas olharam de outra forma para o Brasil, a Venezuela e a Indonésia, todos parcialmente industrializados e com receitas significativas de outros recursos naturais exportáveis e de fácil acesso a crédito. A ânsia desses países de controlar e processar suas próprias matérias-primas desafiou a hegemonia das empresas tradicionalmente dominantes. Isso forneceu não só uma oportunidade para a entrada japonesa, mas também criou a perspectiva de que esses países estariam dispostos a usar seu acesso a crédito fácil, a fim de compartilhar dos enormes investimentos requeridos para a infra-estrutura de energia e transporte e a construção de refinarias e caldeiras de fundição em locais distantes de sistemas de estradas e rede elétrica.

\section{Fatores físicos, ambientais e topográficos na realocação da indústria de alumínio}

Os economistas descritivos das décadas de 20 e 30 compilaram numerosos e detalhados estudos sobre o impacto das mercadorias (commodities) 
primárias e específicas nas economias regionais que as exportavam. Variados estilos de análise econômica, juntamente com a ilusão de que nos meados do século XX os processos extrativos de matérias-primas dominantes, bem mais centralizados e mecanizados, reproduziam processos padronizados de produção industrial, privaram-nos das análises da economia para a maioria dos minerais. A caça, a extração de madeira, a pesca e o cultivo de trigo estão, de forma manifesta, sujeitos a fatores ambientais, topográficos e climatológicos, como também às excentricidades dos mercados internacionais. A atividade de redução do alumínio e mesmo a mineração de ferro parecem compartilhar as relações de capital e trabalho das instalações industriais. Sua associação com sistemas modernos de energia aumenta a ilusão. Argumentarei aqui, entretanto, que os limites físicos e topográficos na extração e no processamento do alumínio podem ser mais bem entendidos fazendo mais analogias com a caça e a extração de madeira do que com a manufatura.

As refinarias de alumina e as usinas de alumínio construídas nos trópicos, nas últimas duas décadas, são maiores, mais intensivos em capital, e usam processos mais modernos que os fornos mais antigos nos países centrais. Para muitas delas tornou-se necessária a construção de usinas hidrelétricas, que estão entre as maiores do mundo. Supervisionadas por engenheiros e técnicos com treinamento universitário e perspectivas globais, elas aparentam ter apenas uma pequena semelhança com as economias exportadoras exóticas, como a caça e a pesca, que eram tão claramente limitadas por fatores ambientais e topográficos. Porém, sua dependência da força hidrelétrica, dos mercados distantes, da larga escala e do entusiasmo dos governos hospedeiros sujeitam-nas diretamente a limites ambientais bastante rígidos. A situação das nações hospedeiras é tão limitada pela localização e topografia como a daquelas que exportam peles e árvores. Todas as tentativas para fortalecer essas economias exportadoras de matérias-primas levaram a grandes investimentos estatais em infra-estrutura, de pouca utilidade ou efeito, que aumentam a dependência do Estado nos créditos altamente instáveis e nos mercados de commodities (vide Innes, 1956).

Ao contrário das suposições evolucionistas populares de que o avanço tecnológico implica confiança reduzida e subordinação no que diz respeito aos fatores naturais e ambientais, a recente injeção técnica nos custos de capital para novos projetos de fundição, juntamente com a desintegração do controle oligopólico de preços e sua substituição pela competição entre empresas estabelecidas e novos competidores, e o esforço da maioria das firmas para reduzir custos de capital e riscos aumentaram a dependência da indústria internacional de alumínio em relação aos fatores naturais. O fim de um sistema socialmente criado de petróleo barato e os desafios nacionalistas em relação ao controle oligopólico sobre as fontes de bauxita criaram aberturas para desafios ao regime de comércio estabelecido. Porém, a fim de sustentar esse desafio, as economias desenvolvidas tiveram que procurar nações que 
combinam capacidade gerencial, acesso a crédito e vantagens naturais decorrentes das características físicas dos próprios minerais e das topografias em que eles ocorrem. Empresas e Estados centrais, embora limitados por fatores naturais, podem escolher entre múltiplos países possuidores de recursos, mas os Estados periféricos só podem pechinchar com fatores naturais absolutamente fixos. Essa rigidez estabelece o cenário para que os Estados centrais e as empresas manipulem a competição entre Estados periféricos e empresas em benefício do centro. Em outras palavras, as nações ricas em recursos naturais são limitadas em sua capacidade de negociar e planejar devido aos mesmos fatores naturais que atraem possíveis investidores futuros.

Não obstante, considerando que esses fatores naturais determinam efeitos sociais e econômicos, deve ser lembrado que decisões sociais criam o contexto econômico e político em que são tomadas decisões sobre a exploração da natureza. A vontade de países hospedeiros de compartilhar os custos tanto de infra-estrutura como das instalações reflete suas aspirações com relação aos efeitos para frente dos recursos do solo. Isso significa, por outro lado, que a mineração, o refinamento e a redução agora tendem a ocorrer no mesmo território nacional, ou que os investimentos são feitos em direção a esse objetivo, mesmo que não exista nenhuma vantagem técnica ou econômica particular para essa forma de integração. Os imperativos sociais e políticos para tal integração territorial contribuem para os limites ambientais de novos empreendimentos, reduzindo o número de locais para usinas de alumínio a algumas localidades geográficas próximas das reservas, do transporte e da energia hidrelétrica.

Podemos voltar agora ao exame desses limites naturais. O mais óbvio de tudo isso é a necessidade de um grande volume de água a ser contida para cair de uma altura apropriada a fim de gerar eletricidade para a usina de alumínio. Um limite ambiental menos claro, porém igualmente significativo, reside nos processos geológicos que formam os depósitos de bauxita economicamente viáveis. Tanto os minérios mono-hidratados como os trihidratados podem ser processados com tecnologias existentes, mas a composição dos tri-hidratados torna a separação do alumínio muito mais fácil e, assim, mais barata e mais limpa para processar. O alumínio liga-se fortemente à sílica, um componente importante da bauxita. A separação desses ligamentos exige muita energia. Contudo, como a silica é solúvel na água, os custos de energia são reduzidos, dependendo da extensão dos períodos geologicamente longos em que a água atua no depósito. Essa condição requer muita chuva por longos períodos de tempo em solo relativamente estável. Como a queda de muita chuva em inclinações exorbitantes causa erosão, os locais mais prováveis para a formação de alumínio tri-hidratados encontram-se em bacias relativamente rasas e com muito tempo de chuva pesada. Isso significa que o alumínio explorável ocorre predominantemente em florestas tropicais, com rios extensos, porém relativamente rasos. 
Tais rios raramente são os locais economica ou ecologicamente mais adequados para a construção de hidrelétricas. Como a geração de força depende do volume de água e da altura da queda, e como a maioria dos rios próximos a depósitos de bauxita economicamente viáveis atravessam bacias relativamente rasas, essas usinas hidrelétricas requerem, freqüentemente, paredes grossas, maciças e extremamente extensas. O alto custo e a complexidade técnica dessas usinas hidrelétricas aumentam tanto a dívida como a dependência. A necessidade de construir paredes extensas e maciças deve-se à topografia, mas determinadas topografias provavelmente não teriam sido selecionadas caso o Estado minerador não tivesse concordado em compartilhar os custos de infra-estrutura e de construção das instalações. A disposição do país minerador de compartilhar esses custos era, porém, significativamente motivada por aspirações visando unir os depósitos de bauxita às refinarias e usinas de alumínio dentro dos limites nacionais.

Essa tendência é mais clara no Brasil, onde uma hidrelétrica estava localizada numa bacia tropical rasa, justamente para uni-la a uma mina de bauxita rio acima. A Indonésia também foi claramente seduzida pela perspectiva de unificar mineração, refino e fundição dentro do território nacional. Isso porque a bauxita, na Indonésia, ocorre numa ilha, e não houve nenhum esforço para instalar a usina rio abaixo em relação à mina. Nesse caso, o local da usina hidrelétrica era altamente favorável em termos físicos, mas ainda mais distante de outros usuários potenciais do que no Brasil. Na Venezuela, um local topograficamente difícil para a mineração foi destinado à instalação de usinas de alumínio, que funcionavam graças a usinas hidrelétricas, construídas com o objetivo de gerar desenvolvimento industrial em áreas tropicais anteriormente muito remotas. Embora as topografias e a seqüencia histórica tenham sido diferentes, nesses casos, em todas elas a participação do país minerador deve-se ao seu seu objetivo de integrar o território nacional a partir da localização natural do recurso. Esse objetivo, de fato, pode induzir esses países a investir em usinas de alumínio, cuja localização, embora não otimizada em termos econômicos e ambientais, é altamente importante em termos políticos.

De fato, até mesmo o tamanho da usina está sujeito a requisitos políticos, além dos requisitos físicos e técnicos da redução e transformação competitiva de alumínio. A fim de justificar os altos custos de capital, a dívida e o deslocamento social, causados pelo estabelecimento de uma usina de alumínio, os Estados nacionais prometem um desenvolvimento associado, baseado em efeitos para frente, utilizando eletricidade. Portanto, as usinas hidrelétricas são freqüentemente planejadas para uma capacidade bem acima daquela exigida para a fundição propriamente dita. Existem inúmeros custos sociais que exacerbam os altos custos financeiros para construir essas usinas enormes. A substituição da altura de queda por volume de água numa bacia rasa cria um reservatório muito maior do que seria necessário para gerar uma quantidade semelhante de eletricida- 
de num local com mais relevo. Mais água deve ser contida, e a água contida cobre uma área maior do que a que seria necessária num vale mais profundo. Os seres humanos, as populações animais e outras economias são, assim, removidos de uma área mais extensa. Como essas áreas são freqüentemente distantes e fortemente arborizadas, a remoção da vegetação antes da inundação é desordenadamente cara. Grandes quantidades de vegetação apodrecida provavelmente podem poluir as águas atrás da usina, ameaçando corroer turbinas e deteriorando a qualidade da água e da pesca. A inundação periódica que fertiliza as bacias dos rios diminui e a maior parte do sedimento fértil fica atrás da usina. Com freqüência, seguem-se à nova inundação também novos vetores de doença.

É geralmente impraticável represar grandes rios navegáveis, tanto devido ao seu tamanho e queda ininterrupta quanto por causa dos custos provocados pela interrupção do transporte fluvial. A localização mais comum de usinas hidrelétricas é, portanto, perto de uma queda, correnteza ou estreitamento de rio. A necessidade de transportar grandes quantidades de material para locais distantes favorece, no entanto, a localização de refinarias e usinas de alumínio em rios maiores, que permitem o acesso a embarcações marítimas. A dispersão progressiva de grandes usinas de alumínio fora das economias do centro, que consomem a maioria de sua produção, aumentou as oportunidades para reduzir os custos de transporte por meio de economias de escala. Desse modo, a combinação do potencial hidrelétrico com um local fluvial adequado para um porto de águas profundas tornou-se crescentemente importante em decisões sobre localização. Assim, as usinas são tipicamente situadas nos grandes rios tributários dos rios principais. A configuração ideal de uma mina, refinaria e fundição é, portanto, um depósito grande de bauxita de alta qualidade, a montante de um rio navegável, além de uma usina hidrelétrica num rio principal, que corre sobre uma escarpa em relativa proximidade à sua confluência com o rio navegável, num ponto suficientemente profundo que permita a construção de um porto, que possa acomodar navios de tonelagem suficiente para aproveitar-se das economias de escala no transporte de longa distância. Essa configuração raramente é realizada de maneira completa, e suas vantagens podem ser substituídas por fatores políticos e geopolíticos como também pelos incentivos e subsídios oferecidos pelos governos nacionais aos investidores. O fator natural nessa configuração limita, porém, diretamente tanto os investidores como os Estados nacionais em suas opções para o investimento e para o desenvolvimento associado.

A transformação de bauxita em alumina é um processo que requer grandes quantidades de água. Isso favorece a localização perto de rios. A localização de usinas de alumínio perto de rios favorece também a localização das refinarias em vias fluviais navegáveis. A lama vermelha - o detrito do processo de beneficiamento - é líquida. A instalação de refinarias perto de rios muito grandes aumenta o perigo de infiltração e poluição, além do custo do controle desse efeito. 
As possibilidades de desenvolvimento adicional na área circunvizinha são parcialmente determinadas pelas características do próprio metal. O transporte dos lingotes e das chapas é menos caro do que o de muitas aplicações acabadas de alumínio, que são ocas e moles. Como esses últimos produtos ocupam muito espaço, seu transporte encarece. Isso reduz bastante a possibilidade de efeitos para frente a partir da transformação do alumínio em áreas tropicais distantes (sobre os limites técnicos e de mercado que favorecem a localização de fábricas perto de centros industriais complexos, ver Marques, 1994).

A associação de grandes quantidades de energia elétrica com os efeitos para frente está na mente de muitos planejadores nacionais, e a eletricidade é um símbolo legítimo e poderoso para os governos nacionais. Tanto Lenin como Roosevelt aproveitaram-se no passado, desse símbolo, que ainda exerce uma forte atração. Os governos nacionais, em suas proclamações sobre parcerias na indústria do alumínio, têm dado ênfase ao potencial dos efeitos das grandes usinas hidrelétricas. De fato, dá-se mais ênfase à publicidade das usinas do que às próprias usinas de alumínio. A menos que existam receitas excedentes disponíveis para o Estado, essas indústrias associadas não parecem ser capazes de materializar-se. Embora com um alto custo e uma série de esforços, que foram nitidamente reduzidos devido à queda dos preços de petróleo e ao aumento da dívida nacional, a Venezuela foi capaz de usar receitas oriundas do petróleo para criar alguns efeitos para frente. A usina de Asahan está situada em um local favorável, em uma área distante; quase nenhum dos projetos de eletrificação prometidos às comunidades dos arredores da usina se concretizou. Os projetos brasileiros na Amazônia estão situados perto de um grande parque industrial, sem um único ocupante. O maior de todos os problemas decorre do fato de as parcerias empreendidas durante esta década justificarem as usinas monstruosas na suposição de que o fundidor pagaria pela maioria dos custos de construção. No entanto, o excesso (ou a superprodução) no mercado mundial que seguiu essas múltiplas parcerias não só reduziu os preços do alumínio primário, mas também levou a uma redução no porte das próprias usinas de alumínio. Freqüentemente, estas pagam taxas de eletricidade fixadas pelo preço do alumínio. Mesmo com os altos preços do alumínio, essas taxas são fixadas bem abaixo daquelas pagas por outros consumidores. Quando os preços do alumínio caíram, em parte devido à contribuição desses projetos para exceder a capacidade, normalmente, as usinas de alumínio acabaram pagando menos do que 20\% dos custos da geração de energia.

A busca de vantagens naturais em áreas tropicais úmidas leva à construção de usinas hidrelétricas em áreas distantes. Muitos dos países menos desenvolvidos selecionados para formar parcerias têm padrões de industrialização significativos, mas regionalmente desiguais. Em tais situações, uma usina pode ser construída em áreas de acesso muito difícil, sem mão-de- 
obra apropriada, ou disponibilidade de materiais, e por engenheiros que não estão familiarizados com o meio ambiente e não têm experiência com projetos dessa escala. Todos esses fatores podem aumentar os custos de construção de uma usina hidrelétrica, limitando, ao mesmo tempo, os outros usos da eletricidade gerada. Os agentes das empresas e Estados do centro que promoveram o investimento na usina e na infra-estrutura associada podem defender-se argumentando que os Estados periféricos estão subsidiando a exportação de eletricidade para o centro a um custo alto devido à incompetência e à corrupção local, que levaram à alta do custo e ao fracasso em vender mais eletricidade. Essa argumentação ignora os custos extras de Estados inexperientes, que se encarregam de fazer projetos que não conhecem, em áreas distantes. O resultado mais freqüente dessas estratégias do centro é que essas usinas, ao invés de constituir fatores de crescimento, tornaram-se "elefantes brancos" altamente endividados, além de limitar a capacidade das companhias elétricas de fazer as expansões necessárias em áreas mais desenvolvidas de seus países.

Dois conjuntos de fenômenos - um físico, químico, geológico e topográfico, e o outro tecnológico, político e econômico - cruzam-se para determinar a escala, a localização e a operação das usinas de alumínio. Enquanto as decisões políticas no país minerador entram no processo de negociação e em última instância determinam se um projeto vai adiante ou não, o Estado minerador defronta-se com a escolha entre vetar ou aceitar um projeto formado por esses dois conjuntos de fenômenos. O país minerador não tem controle sobre nenhum desses fenômenos e cada um deles tampouco se forma em interação com as ações do Estado. Pelo contrário, o Estado no páis minerador procura maximizar os rendimentos sobre dois recursos naturais separados - a bauxita e a hidroeletricidade - em mercados relativamente inflexíveis, estruturados quase completamente pela demanda e distantes da localização natural dos recursos naturais. O modelo de desenvolvimento regional articulado (de linkage) oferece possibilidades atraentes, mas somente às custas de alto investimento de capital. A transportabilidade natural da alumina, junto com as economias de escala no refino e o custo relativamente baixo de capital por tonelada, que causou a capacidade excedente nas refinarias, efetivamente pressionou o modelo de sistema articulado (linkage), deixando tanto a Indonésia como o Brasil dependentes dos mercados exportadores de bauxita, enquanto continuavam a importar alumina para suas caras usinas de alumínio. Retornaremos, mais tarde, as razões pelos quais o elo prometido entre mina e usina de alumínio não se concretizou. Importa ressaltar aqui que fatores naturais induziram os Estados que buscavam o sistema articulado (linkage) a fazer grandes investimentos hidrelétricos e de fundição, mas outros fatores naturais, i.e., o custo relativamente baixo do refinamento e do transporte da alumina contribuiu para romper a cadeia em que esses enormes investimentos e dívidas foram baseados. 


\section{Matérias-primas e a inconstante hierarquia do sistema mundial}

As economias nacionais em ascensão no sistema mundial elaboram estratégias especialmente agressivas para garantir o acesso às matériasprimas. Sua ascensão começa normalmente durante períodos de expansão econômica global, quando a demanda por matérias-primas industriais e pela infra-estrutura se aproxima da capacidade ou a ultrapassa, elevando os preços. Sua necessidade de maior oferta excede a média global de forma acelerada, mas a hegemonia estabelecida geralmente capta a maioria das fontes, controla os mercados internacionais e ainda consegue dominar as tecnologias de extração e de transporte. A ascensão sustentada, para tanto, requer que as economias em desenvolvimento explorem as oportunidades e as debilidades das relações políticas e econômicas estabelecidas, que regem a extração e a exportação de matérias-primas.

As relações entre empresas e Estado nas economias em ascensão determinam os limites e as possibilidades das estratégias coordenadas de acesso às matérias-primas, permitindo particularmente a transformação dos interesses convergentes e divergentes de empresas em pontos diferentes na cadeia de produção, com um planejamento econômico global. A relação do Estado com as empresas e com as classes sociais que possuem terras nas nações exportadoras, como também sua posição na economia mundial, influenciam sua habilidade de fazer um bom negócio e de aproveitar-se da estrutura variável do sistema mundial. Entretanto, geralmente as tensões em torno das estratégias competitivas de hegemonias em ascensão exacerbam a instabilidade, os custos ambientais, a tendência de quebrar acordos de comércio e a dependência tecnológica inerente às economias de extração de recursos. Esse resultado é paradoxal. Com a finalidade de ganhar a colaboração das nações exportadoras de recursos, os Estados e as empresas de economias em ascensão freqüentemente manipulam as aspirações que estas têm em relação à independência econômica e política ou em relação ao desenvolvimento. Freqüentemente, essa colaboração é necessária para retirar o controle de hegemonias estabelecidas sobre os fluxos de matéria-prima. A economia em desenvolvimento pode oferecer assistência contra o controle colonial direto, ou auxílio no desenvolvimento do transporte ou da infraestrutura. Contudo, se o desafio em relação à hegemonia estabelecida é vencido, isso pode mudar significativamente a estrutura do mercado mundial e das indústrias primárias, de tal forma que resulte em vantagem, enquanto subordina exportadores periféricos de recursos, num jogo com regras profundamente modificadas. Isso significa que os esforços feitos pelas periferias extratoras de recursos para reduzir sua subordinação podem ter grandes conseqüências no sistema mundial. Entretanto, eles tendem a fortalecer certas economias centrais e a prejudicar as periféricas. No caso do alumínio, mostraremos que os japoneses manipularam o nacionalismo de vários Estados, que estavam preocupados em promover um sistema de desenvolvimento articulado (de linkages) a partir de seus recursos naturais, induzindo-os a 
investir em usinas de alumínio. A entrada de usinas estatais, financiadas com dívidas múltiplas e com compromissos de exportação para o Japão, debilitou seriamente os estabelecidos oligopólios norte-americano e europeu, mas a capacidade excedente resultante exacerbou a tendência de queda dos preços, deixando os exportadores de recursos com grandes dívidas e pouco, ou quase nenhum, retorno para seus investimentos.

\section{As economias em desenvolvimento e suas estratégias de acesso aos recursos}

As estratégias agressivas de economias em desenvolvimento em relação aos recursos são determinadas (1) pelos requisitos tecnológicos, financeiros, políticos e militares de acesso ao mercado e ao controle durante o período de sua ascensão, (2) pelos efeitos cumulativos da extração de recursos e pelo tamanho e localização de reservas conhecidas. Os mercados e as tecnologias determinam quais as matérias-primas mais críticas para o crescimento dessas economias. O número de fontes economicamente viáveis da matéria-prima específica, sua localização espacial, topográfica, sua localização dentro dos limites nacionais influenciam as estratégias de empresas e de nações, como também a posição das diferentes nações exportadoras e importadoras dentro do sistema mundial.

No passado, a expansão colonial da Inglaterra era motivada em grande medida pela necessidade de obter madeira, tanto para a construção de navios como para o abastecimento das usinas de ferro (Albion, 1926). As estratégias britânicas de expansão eram condicionadas pela condição demográfica e política das Américas e da Austrália e também pela competição com a França. O Estado britânico encorajou as firmas madeireiras a investir no Canadá, quando a França ameaçou o acesso britânico às florestas balcânicas. Para tal realização, a Inglaterra teve que fornecer incentivos e proteção para superar a relutância dos capitalistas em investir no custo maior da localização norte-americana mais segura (Albion, 1926). Dois séculos mais tarde, a Inglaterra usou estratégias muito diferentes para garantir o acesso aos minerais que estavam substituindo rapidamente as fibras como matérias-primas críticas. Para isso, explorava brechas nos sistemas coloniais espanhol e português e nas recém-independentes classes dominantes latinoamericanas, a fim de quebrar barreiras comerciais e garantir concessões para a extração de recursos e, mais tarde, para induzir Estados nacionais a assumir parte dos custos ou todos os custos da construção dos sistemas de transporte necessários à exportação de matérias-primas (Hobsbawn, 1968; Cardoso e Faletto, 1979).

As estratégias norte-americanas para garantir o acesso aos minerais durante a ascensão para a preeminência industrial e militar constituíram uma reação à diferente organização política mundial, no início e nos meados do século XX. Nas décadas de 20 e 30, o Conselho de Relações Exteriores elaborou esquemas geopolíticos para garantir o acesso a matérias críticas e 
estratégicas. Além disso, propôs_também às instituições financeiras internacionais a estabilização de fluxos de investimento e de custos. A II Guerra Mundial e a Conferência de Bretton Woods criaram as condições para a realização concreta desses esquemas. Assim como a Inglaterra fez no século XIX, na década de 20, os EUA, nos anos de 1940 e 1950, manipularam as aspirações nacionalistas para garantir o acesso aos recursos, que estavam sob o controle colonial europeu. Utilizaram-se também da desesperada necessidade da Europa de obter capital, impedindo o acesso a matérias-primas em colônias francesas, britânicas e holandesas por meio da ameaça de retenção do Auxílio Marshall (Bunker e O’Hearn, 1992). O Banco Mundial e o FMI foram projetados para aliviar as distorções econômicas causadas pela intervenção política e econômica dos E.U.A. em países exportadores de matérias-primas, por meio da estabilização de moedas, a fim de proteger a extração e o comércio de matérias-primas, além de assegurar a continuação das exportações apesar das crises econômicas.

Os japoneses defrontaram-se com uma situação muito diferente quando começaram sua ascensão industrial na década de 60. Os Estados Unidos enfrentaram um sistema imperial debilitado por forças industriais descapitalizadas, que já se encontravam em relativo declínio. Os japoneses enfrentaram a economia norte-americana, ainda em expansão vibrante, política e economicamente, que controlava diretamente a maioria dos recursos naturais mediante investimentos e propriedade direta. Alguns dos minerais mais críticos eram controlados por oligopólios situados na Europa e nos Estados Unidos (Vernon, 1983; Oman, 1989). Após a II Guerra Mundial, os japoneses tinham muito menos capital à sua disposição em comparação com os EUA. Nos anos subseqüentes, a escala de extração, de processamento e de tecnologia de transporte para a maioria dos minerais aumentou, e muitas nações subdesenvolvidas, porém ricas em recursos naturais, ficaram muito mais exigentes em seus contratos referente aos recursos. Os japoneses também tiveram que enfrentar a manifestação mais dramática dessas exigências na fase mediana de sua ascensão quando a OPEC forçou o aumento dos preços de petróleo em 1973 e 1979, aumentando enormemente os custos de energia para o processamento industrial e para o transporte de matéria-prima.

Os japoneses reverteram alguns desses obstáculos em seu próprio benefício. Eles resolveram os problemas de escala de investimento incrementada em extração e processamento e de exigência nacionalista para o controle e o desenvolvimento da extração mineral, seduzindo nações ricas em recursos naturais para que estas se tornassem parceiras com dívidas financiadas para as minas e as usinas. Os grandes excedentes de capital financeiro que resultaram dos choques de petróleo na década de 70 facilitaram essas novas formas de investimento. O nacionalismo em relação aos recursos e as projeções otimistas do consumo mineral feitas pelo Banco Mundial, como também pelo Ministry of International Trade and Industry - MITI no Japão, junto com a promoção do Banco Mundial para a criação de elos no final da 
cadeia de produção (downstram linkages) da mineração, encorajaram muitos Estados pobres e endividados a assumir níveis ainda maiores de endividamento, na esperança de ter o controle soberano e tecnológico de seus próprios recursos, além de obter mais valor agregado nas vendas, no processamento e na fabricação.

Assim como os ingleses e os americanos, os japoneses tiraram proveito das aspirações de nações periféricas, propondo a expansão de sua participação e benefício no que diz respeito à extração e à importação de matérias-primas. A utilização de parcerias com minoria participativa garantiu o acesso direto a matérias-primas, com um risco de capital relativamente pequeno (Ozawa, 1979; Oman, 1984; Bomsel et. al., 1990). No caso do alumínio, a proliferação de parcerias com Estados nacionais separados, que não coordenavam suas próprias estratégias, fez com que houvesse bastante oferta excedente no mercado, com o objetivo de quebrar o poder do oligopólio das seis empresas que regulavam o preço e controlavam os mercados, durante a década de 60. Os japoneses não realizaram isso sozinhos. Várias empresas menores, algumas delas japonesas, entraram no mercado na década de70 e forneciam bastante alumínio desconectado (untied) para criar um mercado instantâneo. Os japoneses, entretanto, intensificaram e aceleraram as pressões sobre o oligopólio. Primeiramente, usando o mercado instantâneo de forma extensiva e, depois, estimulando de forma ativa novas capacidades. Cinco empresas japonesas associaram-se ao London Metals Exchange (LME), em 1975. O preço do alumínio foi determinado pelo LME pela primeira vez em 1977, e os japoneses estavam entre os primeiros e maiores compradores de alumínio no LME até que a produção de suas parcerias foi posta no mercado, nos anos 80.

O investimento estrangeiro direto e o subseqüente controle sobre todos os aspectos da mineração, do processamento e da formação de preços pelas empresas norte-americanas e européias causaram o ressentimento e a resistência por parte de vários países exportadores de recursos naturais. Em parte, a estratégia japonesa era eficaz porque pareceu ser sensível às aspirações desses países, a fim de obter maior controle sobre os recursos e maior valor agregado pelo processamento antes da exportação. As parcerias são relativamente imunes das críticas nacionalistas, pois os novos empreendimentos são formalmente nacionais. Mesmo depois que a redução de preços pela capacidade excedente combinou-se com a absorção estatal nacional dos custos com a infra-estrutura, aumentando os níveis da dívida e dos déficits públicos, o Estado e suas companhias eram obrigados a manter os compromissos assumidos com o que, freqüentemente, se tornou um custoso "elefante branco" (Bomsel et. al., 1990).

O sucesso japonês, nessa estratégia, substituiu antigas formas de subordinação baseadas em investimento estrangeiro direto na extração mineral e no controle oligopólico de mercados mundiais de minerais por novas formas de subordinação, baseadas em competição entre múltiplos fornece- 
dores endividados, num mercado desestabilizado pelo descoordenado excesso de capacidade. Essa estratégia, por deslocar para frente o locus de lucro excedente na cadeia de mercadorias (commodities), que por sua vez permitia (a) o aumento dos custos tecnológicos e dos custos de construção de novos projetos de mineração e (b) a redução dos preços dos metais básicos, debilitou enormemente os oligopólios estabelecidos, cujo capital encontrava-se largamente vinculado à extração primária, totalmente própria e autofinanciada (Oman, 1984: 43, 45, 46, 67, 68). O acesso à participação em fundos de dívida de capital por diversos países mineradores e a liberação de capital empatado em minas obsoletas e instalações de processamento deram aos japoneses muito mais liberdade para fazer o jogo que eles mesmos estavam promovendo. As empresas de mineração mais antigas foram forçadas a entrar no mesmo jogo, mas seus pesados compromissos existentes em relação às minas totalmente próprias e aos hábitos desenvolvidos durante o período de controle oligopólico lhes dão muito menos liberdade de ação que os japoneses. Dessa forma, as companhias mais antigas exacerbaram as condições que levaram à sua própria perda de controle, aumentando a descoordenada capacidade excedente, que provoca a redução dos preços. Os japoneses, com uma participação proporcionalmente menor em suas parcerias individuais em comparação com as companhias norteamericanos, diminuíram seus riscos e aumentaram seus ganhos (Bomsel et. al., 1990).

As companhias mineradoras mais antigas podem ter contribuído também para o colapso dos oligopólios por sua anunciada relutância em investir no contexto do crescente nacionalismo quanto aos recursos naturais. Oman (1984: 68) adverte que a queixa de que a propriedade nacional e o controle de recursos minerais em países em desenvolvimento produzirão uma capacidade excessiva e, portanto, limitarão a vontade de investir, constitui um argumento que pode ser usado (a) por oligopólios estabelecidos na esperança de desanimar mais a diversificação da oferta e (b) por consumidores encorajando os bancos multilaterais e comerciais a investir, a fim de compensar essa suposta relutância. Se os bancos multilaterais e os Estados aos quais eles servem considerarem seriamente a ameaça de reduzir o investimento, podem provocar exatamente o resultado que se pretende evitar com a ameaça, i.e., a expansão rápida e descoordenada de investimento e a criação de capacidade excessiva.

De fato, tanto os bancos multilaterais quanto os comerciais têm reforçado essa tendência em direção à capacidade excessiva. Grandes contas de excedentes e balanças comerciais positivas no Japão e na Europa, no início da década de 70, levaram os bancos comerciais a procurar novas oportunidades para empréstimos. Radetzki (1980) afirma que o financiamento externo para projetos minerais cresceu menos de 20 \% do total (antes dos anos 60), para níveis entre 60 e 80 \% (citado em Bomsel et. al., 1990: 44). "Enquanto cerca de 80 a 90 \% dos fundos de investimento em projetos de mineração em 
países em desenvolvimento entrou na forma de capital de participação até mais ou menos 1960, durante a década de 70, a proporção era de apenas cerca de um terço" (Oman, 1984: 46).

Quando as companhias de mineração reagiram ao nacionalismo em relação aos recursos naturais, ameaçando reduzir os investimentos, e quando os países industriais do centro começaram a se preocupar com os cartéis mineradores (fora o petróleo), o Banco Mundial respondeu, principalmente, com sanções contra os países que nacionalizaram os projetos de mineração. Mezger (1980) mostra que os empréstimos concedidos ao Chile - pelos bancos multilaterais e de desenvolvimento, inclusive o Banco Mundial - foram efetivamente suspensos depois da nacionalização de suas minas de cobre e foram retomados depois que o governo Pinochet fez grandes concessões às companhias mineradoras estrangeiras. Porém, ao final da década de 70, o Banco Mundial incentivava realmente os Estados periféricos a investir em projetos de recursos naturais. O Banco concedia empréstimos para projetos em infra-estrutura relacionados à extração e ao processamento mineral. Divulgou projeções otimistas de consumo, que fortaleceram enormemente as propostas de agências estatais periféricas e de empresas ansiosas para fazer parte de projetos de mineração. Deu também pareceres favoráveis aos investimentos em transporte, energia e infra-estrutura nos países periféricos (ver, por ex., Nankani, 1979).

Posteriormente, quando surgiu a crise da dívida internacional, o Banco Mundial buscou formas defensivas de conceder empréstimos às nações altamente endividadas, a fim de estabilizar os mercados de crédito internacional. Um dos mecanismos utilizados foi o de coordenar os empréstimos de diferentes bancos nacionais de exportação e importação especificamente nos grandes projetos. Existiam, desse modo, vários e diferentes conjuntos de interesses em tornar disponível um amplo crédito aos países ricos em matéria-prima e empresas mineradoras para ter maior participação em projetos de extração e processamento mineral.

O otimismo excessivo do Banco Mundial sobre a promessa de grandes projetos de mineração e suas previsões de preços estáveis contínuos, deliberadamente ou não, animaram os Estados periféricos a investir em projetos de mineração, servindo, desse modo, às necessidades das nações industriais do centro de assegurar ofertas baratas e estáveis de matérias-primas. O Banco Mundial, pelo fato de emprestar seu prestígio e know-how técnico para a aprovação de projetos complexos, em alguns casos facilitou o financiamento articulado pelos bancos de exportação e importação de Estados centrais, interessados na obtenção mineral para suas próprias nações.

Bomsel et. al. (1990: 44) consideram que o Banco Mundial expandiu de forma deliberada a capacidade de mineração em nível internacional. Os serviços do Banco Mundial responsáveis pela monitoração dos mercados de matérias-primas minerais fizeram, de fato, as mais exageradas e "otimistas" previsões de demanda a médio prazo nos anos 70. No entanto, em nossa 
opinião, isso ocorreu não tanto por causa da cegueira científica mas principalmente por causa da convicção de que era dever do Banco promover o desenvolvimento da capacidade nesse setor (cf. estudos publicados pelo Serviço de Previsões de Mercado do Banco Mundial, no final da década 70).

Bomsel et. alii. também sugerem que as empresas e nações consumidoras fizeram pressão tanto nos bancos comerciais como junto aos bancos multilaterais para financiar a formação de parcerias na exploração de matérias-primas, a fim de evitar a escassez quando as corporações multinacionais começassem a mostrar relutância em investir seu próprio capital de participação em propriedade direta. Essa campanha das agências financeiras para promover a capacidade da mineração serviu diretamente aos interesses das nações centrais em assegurar ofertas adequadas de matériasprimas para manter a expansão industrial e a acumulação internacional. Essa campanha justificava-se, para os países que garantiriam a maioria dos custos da dívida crescente, pela noção respeitável, porém empiricamente duvidosa, de que nações subdesenvolvidas poderiam obter capital para investimento e pagamento da dívida, mediante exportações de matérias-primas (cf. Bosson e Varon, 1977; para uma história e crítica dessa idéia, vide Bunker, 1989a). Os países mineradores eram particularmente vulneráveis a tais tentações. Muitos deles instalaram agências especiais e empresas estatais a fim de aumentar as receitas que poderiam obter com a extração de recursos. Essas empresas e agências desenvolveram um know-how considerável, mas geralmente consideravam seus próprios interesses expansionistas ou de proteção de mercado. Elas poderiam usar as projeções otimistas de mercado e o modelo de desenvolvimento dirigido para a exportação de recursos para obter o apoio e freqüentemente incentivos fiscais especiais do Estado nacional. As agências e empresas de Estados centrais podem manipular de forma semelhante as projeções de mercado e os modelos de desenvolvimento. Tanto na mineração de ferro quanto na redução eletrolítica de alumínio dos projetos brasileiros discutidos abaixo, a empresa estatal brasileira de mineração, em suas negociações com o governo nacional e com os governos de Estados locais, usou as projeções de mercado e os modelos de desenvolvimento do Banco Mundial e das agências japonesas de planejamento.

A crescente participação de capital financeiro internacional em projetos mineradores não só envolveu a participação estatal periférica naquilo que pode vir a ser capacidade excessiva, mas também transferiu uma parte crescente do custo dos projetos mineradores para o setor público. O financiamento público internacional de projetos de mineração tendeu a separar os investimentos em infra-estrutura - que, normalmente e ainda sob formas oligopólicas do IDE (Investimento Direto Externo) em mineração, eram assumidos pelas companhias mineradoras - do investimento nas minas ou no processamento. Dessa forma, os bancos de desenvolvimento podiam conceder empréstimos soberanos às nações para a construção de usinas hidrelé- 
tricas, estradas, portos e ferrovias, como se fossem projetos de desenvolvimento em si mesmos, com a promessa atraente de que a maior parte de seus custos seria compensada pelas receitas minerais. Dessa maneira, os empreendimentos mineradores eram liberados de uma porção maior do capital de risco, enquanto o Estado e os bancos de desenvolvimento podiam invocar as teorias de sistema de encadeamento (linkage) para justificar os gastos com a infra-estrutura (vide Bunker, 1989a). Em tais casos, o Estado não recebe receitas de um sócio-proprietário (parceiro), mas conta com impostos, além dos efeitos colaterais em potencial para recuperar seu investimento. Justamente por isso, a infra-estrutura não entra na contabilidade do lucro e prejuízo para o empreendimento mineral. Desse modo, no país hospedeiro, as empresas nacionais e o Estado dependem de forma mais direta de receitas no início da cadeia de produção, enquanto as empresas multinacionais que possuem menos participação acionária podem beneficiar-se com seu acesso maior aos mercados, com sua capacidade de lucrar com a venda de tecnologia e licenciamentos, com seu acesso contínuo a informações internas sobre política mineral local e com o ganho político que suas associações com as elites nacionais lhes oferecem. Além disso, o envolvimento de bancos internacionais protege-as de alterações desvantajosas em contratos e concessões, como também da ameaça de expropriação, à qual eram muito mais vulneráveis quando se autofinanciavam como investidores estrangeiros diretos (Girvan, 1980; Oman, 1984).

A capacidade excedente resultante poderia tornar-se uma ameaça para os consumidores se ela eventualmente desencorajasse maiores investimentos, levando, assim, à escassez. Mas, no curto e no médio prazo, a diversificação de fontes por parte de Estados incapazes de reduzir significativamente a produção, por causa de obrigações de crédito ou de compromissos políticos com a classe operária e com as elites nacionais, garante ofertas relativamente seguras. Assim como os japoneses parecem estar fazendo, no momento, com o minério de ferro, o controle contínuo de informações e de finanças pode presumivelmente permitir aos consumidores de nações centrais manipular o aumento dos preços ou, caso contrário, estimular o investimento quando períodos de escassez são previstos.

\section{O impacto da competição do centro nas periferias exportadoras de recursos naturais}

As alterações de hierarquias no sistema mundial do centro, com a aceleração da expansão da produção industrial, têm uma série de implicações profundas para as periferias extrativas de recursos. A expansão da produção industrial requer a expansão da extração de recursos. Ambas as expansões requerem investimento do capital, acumulado em uma circulação anterior, que se expandiu mediante a transformação anterior de matérias-primas em mercadorias (commodities). Ciclos anteriores freqüentemente reduzem ou esgotam as fontes de recursos mais próximas ou mais convenientemente 
situadas em relação aos locais de transformação industrial. A escala tecnológica e de investimento normalmente aumenta durante e entre os ciclos de expansão, e assim são necessários depósitos maiores para cada ciclo subseqüente. A redução de fontes mais convenientes e a escala crescente associam-se para deslocar o locus de extração para lugares mais distantes dos centros geográficos da indústria mundial e, assim, mais longe da infraestrutura estabelecida de transporte, comunicação e energia, e também além dos limites espaciais das instituições de propriedade privada, de crédito, de relações trabalhistas e de mão-de-obra, que se desenvolveram com a indústria capitalista. O imperativo espacial forjado pela interseção da demanda expandida, da crescente escala tecnológica e da distribuição geologicamente determinada de depósitos economicamente viáveis incorpora novas periferias ao sistema mundial, exclusivamente com base nos recursos aí encontrados e nos efeitos de suas topografias e climas sobre os custos de extração e exportação. A escala de extração incrementada associa-se à distância crescente do locus de transformação industrial para aumentar a importância de economias de escala no transporte. Assim, são construídas, em torno do empreendimento extrativo unitário, extensas e caras ferrovias, estradas e portos. Há, então, uma tendência crescente na extração de recursos para impor amplos regimes de capital intensivo nas regiões com pouco ou nenhum outro vínculo com a economia capitalista mundial. Isso aumenta tanto o custo de capital quanto o custo social, além de concentrar, freqüentemente, danos ambientais. Quando as empresas e o Estado de uma economia em ascensão colaboram para superar ou solapar os controles políticos e de mercado de empresas e de Estados hegemônicos estabelecidos, os custos sociais, ambientais e de capital provavelmente aumentarão. Em alguns casos, as estratégias de acesso dos países centrais podem exacerbar a competição dentro das nações periféricas e entre elas, o que pode levar à violência e à guerra. Esse tipo de competição, em muitos casos, provoca também a exploração acelerada do recurso, além da capacidade excessiva no mercado mundial, de maneira que pode levar à queda de preços, prejudicando, assim, a economia exportadora.

\section{O problema da capacidade excessiva}

O imperativo fundamental que desloca fronteiras de recursos - as necessidades das nações industriais de fontes baratas e seguras de matériasprimas - pode ser satisfeito de vários modos. O ideal, na perspectiva das nações centrais, seria um mercado completamente livre, em que nações ricas em recursos naturais competissem para maximizar suas próprias vantagens comparativas. Tal mercado livraria as nações consumidoras dos custos extra-econômicos para garantir o acesso mediante intervenção política, incentivos econômicos e coerção, o que serviria de defesa contra outras nações consumidoras. Tal sistema seria, e historicamente tem sido, totalmente vulnerável a qualquer nação central que tentasse aumentar sua vanta- 
gem a curto prazo ou se esforçasse para impedir que outra nação fizesse a mesma coisa.

Na ausência desse mercado livre ideal, os Estados e as empresas planejam suas próprias e mais caras estratégias. Três dessas estratégias parecem particularmente relevantes para a consideração da indústria do alumínio. Primeiro, várias nações impuseram um controle imperialista, em que um Estado colonial regulava as condições de extração, a direção de comércio e os preços de recursos. Entretanto, os sistemas coloniais são caros para manter e geram resistência. Um segundo meio de garantir o acesso seria mediante investimentos preventivos - baseados em algumas combinações de controle de patente e contrato exclusivo com o Estado exportador. As empresas mantidas por Estados nacionais que buscam segurança de acesso são freqüentemente capazes de formar monopólios ou oligopólios, isto é, acordos reguladores da produção entre um pequeno número de grandes firmas. A capacidade dos monopólios e oligopólios para controlar taxas de extração e regular preços pode causar também a oposição dos países ricos em recursos naturais, uma vez que tais mecanismos limitam suas receitas a curto e a médio prazo. Um terceiro meio de segurança de acesso é induzir a diversificação de fontes, a fim de criar um mercado competitivo.

A escolha real e a implementação da estratégia refletem as relações entre as nações centrais e os meios disponíveis para subordinar as nações periféricas, por meio de custos economicamente viáveis. Refletem também a natureza da commodity propriamente dita e as condições dos mercados, naquele momento.

Tanto a segunda como a terceira dessas estratégias podem envolver a manipulação de capacidade excessiva, porém de formas e com conseqüências muito diferentes. Visando vantagens monopolistas e oligopolistas, as empresas podem esforçar-se para ter uma capacidade excessiva a fim de intimidar novos concorrentes no mercado. Tais estratégias foram descritas teoricamente, mas casos reais são difíceis de identificar na indústria. Entretanto, como Barham sugere (1994), algumas formas de extração natural de recursos prestam-se à capacidade excessiva de forma relativamente fácil. Não no sentido de construir fábricas e instalações, o que normalmente é muito dispendioso, mas no sentido de comprar ou arrendar depósitos minerais mais favoráveis ou os locais geradores potenciais de energia, com rendas baseadas não no uso potencial, mas no uso presente. Se os depósitos se localizam longe de outros investimentos, esses arrendamentos podem ser extremamente baixos. O controle de informação técnica e de prospecção pelas companhias pode ser crucial para a obtenção de arrendamentos baixos nesses contratos preventivos (vide o caso da Jamaica em O'Hearn, 1994, e do Canadá em Barham, 1994).

Essa estratégia de manter depósitos minerais em uma reserva estratégica, de fato, cria capacidade excessiva somente como um potencial para a companhia que possui os direitos de extração. Ela não leva à oferta exces- 
siva no mercado. Pode limitar as receitas para o país hospedeiro afetado, mas normalmente funciona para a manutenção da alta dos preços. De fato, se a estratégia de intimidação dos concorrentes é bem-sucedida, os oligopólios tenderão a manter a oferta em baixa, conservando, assim, os recursos naturais e limitando o desperdício. Como o oligopólio controla as reservas estratégicas da matéria-prima, é provável que a vantagem ecológica seja explorada. Isso significa que a extração e o processamento serão situados da maneira menos dispendiosa possível. É possível, portanto, que, ecologicamente, a estratégica de reservas estratégicas seja relativamente eficaz. Nesse sentido, é diametralmente diferente, em seus efeitos, da terceira estratégia, i.e., a diversificação induzida.

As estratégias de diversificação expandem, necessariamente, a capacidade, e a diversificação agressiva pode levar à capacidade excessiva. O problema é que estratégias de diversificação requerem a construção real de capacidade de processamento em vez da simples posse das reservas e, desse modo, requerem muito mais investimento de capital. Os custos elevados dessa estratégia são altamente problemáticos, pois a expansão de capacidade pode precipitar um declínio de preços e, assim, diminuir o retorno do capital investido. É por essa razão que a vontade de países mineradores de participar nos investimentos tornou-se crítica para as estratégias de diversificação. O problema é que o investimento do país exportador de matéria-prima nessas estratégias de diversificação transfere uma grande parte do risco de capacidade excessiva para os países periféricos mais pobres. As empresas e os bancos dos países centrais podem sofrer com algum declínio de preços, mas, no geral, indústrias e consumidores dos países centrais beneficiar-se-ão, tanto com a estabilidade da oferta, como com os preços mais baixos.

O sucesso de Estados e de empresas do centro de transferir alguns dos riscos da capacidade excessiva para os Estados periféricos foi descrito com palavras um tanto diferentes, como "Novas Formas de Investimento Internacional" (NFII). Oman (1984, 1989) e Bomsel et. al. (1990) estão particularmente preocupados com o movimento atual do IDE sob o controle oligopólico das NFII. Essa preocupação existe principalmente em relação às parcerias, como um reflexo da internacionalização de mercados, dos custos tecnológicos crescentes e da instabilidade de mercado. Os autores reconhecem que os japoneses têm sido particularmente agressivos na busca de parcerias estrangeiras, e que os americanos têm sido menos agressivos que os alemães e os japoneses. Reconhecem, ainda, que ambos os governos nacionais da Alemanha e do Japão têm coordenado ativamente as estratégias de investimento na mineração de empresas nacionais. Eles não reconhecem, todavia, que os japoneses têm usado as NFII de forma estratégica para superar as barreiras que um regime hegemônico estabelecido criou para assegurar o acesso a matériasprimas. Eles também não consideram até que ponto as mudanças na hierarquia da economia mundial trouxeram alterações semelhantes para a composição de investimento em períodos anteriores. Por exemplo, apesar do domí- 
nio do capital estrangeiro nos mercados internacionais de borracha, os capitalistas locais controlavam as redes internas que transferiam a borracha do local de extração para os portos internacionais. As tentativas de controle estrangeiro direto da extração de borracha falharam tristemente (Weinstein, 1983a, 1983b). De forma semelhante, o Estado peruano administrou a extração de guano (acumulação de fosfato de cálcio resultante de excremento de aves marinhas), embora ele não tivesse nenhum controle sobre seu transporte ou sobre seus mercados externos. O colapso dos preços de açúcar correspondeu à entrada de múltiplos empresários locais. A Hennequin foi financiada, em grande parte, por interesses norte-americanos, mas sob o controle local. Há, portanto, casos históricos que mostram a variação e a mistura dessas diferentes estratégias; não há um momento histórico em que uma substitui a outra. Geralmente, o interessante sobre as NFII é que o controle indireto foi usado de forma muito efetiva pelo capital do centro, quando as condições políticas e econômicas que controlavam a extração de matériasprimas industrialmente críticas favoreceram tal estratégia. Em todos esses casos, o controle indireto delegou uma grande parte do risco político e de capital ao Estado da nação exportadora ou a algumas frações de sua classe dominante. Esses Estados e classes e as sociedades que eles controlavam foram, freqüentemente, prejudicados de maneira severa quando esses mercados instáveis declinaram. No modo anterior de controle oligopólico, os custos de investimento crescentes teriam elevado as já consideráveis barreiras de entrada. O entusiasmo pela participação nacional em projetos de mineração, junto com o crédito fácil do início da década de 70, fortalecido pelas metas do Banco Mundial e de outras instituição financeiras para reestabilizar os mercados minerais - a fim de evitar cartéis de mineração parecidos com a OPEC e para gerar fluxos de capital para as nações endividadas -, convergiram para transformar essas potenciais barreiras de entrada em oportunidades de compartilhar os custos de investimento com as nações hospedeiras. Aparentemente, algumas dessas nações ou empresas entraram no mercado com a expectativa de que suas grandes reservas e seus projetos gigantescos lhes permitiriam controlar os mercados da mesma forma que os oligopólios de antigamente o fizeram. Esse erro estratégico e os antigos modelos de mercado nos quais se baseavam foram exacerbados por projeções excessivamente otimistas do Banco Mundial sobre a demanda mineral e de preços, baseadas nas experiências anteriores de preços estáveis sob controle oligopólico do mercado (Bomsel et. al., 1990). A capacidade real e a capacidade projetada de muitos minerais cresceram de modo selvagem até a queda do mercado de minerais no princípio da década de 80. O declínio da capacidade excessiva e do preço exigiu, então, reajustes e reestruturação de dívidas em toda a indústria mineral mundial. Os japoneses, entretanto, estavam numa situação muito melhor para se adaptar à crise, devido a suas políticas de estabelecer parcerias. De fato, no momento da queda, os japoneses tinham menos capital investido em parcerias de mineração em comparação com as 
companhias norte-americanas ou européias, mas, por outro lado, eles tinham um maior número de parceiros. Desse modo, eles tiveram mais efeito e mais controle com menos capital, além de estarem muito menos expostos ao declínio dos preços e muito melhor posicionados para aproveitar-se desses preços como consumidores finais do que os membros dos oligopólios, de cujo controle eles conseguiram fugir.

Os efeitos dessa competição em economias extrativas regionais foram severos. Por causa da escala de empreendimentos mineradores únicos e porque a maioria de tais empreendimentos define as diferentes regiões isoladas em que estão estabelecidos, as economias extrativas estão desordenadamente estruturadas pelas tecnologias e condições de extração de um ou alguns recursos naturais. As características físicas do recurso, as formas tecnológicas propícias para sua extração e processamento, a escala de investimento necessário e a topografia ao redor influenciam as formas de destruição e de desenvolvimento. O isolamento relativo de atividades extrativas requer uma porção maior de investimento total, freqüentemente entre 60 e 70 \%, seja necessária para a construção de infra-estrutura de transporte, de energia, e residencial (Bosson e Varon, 1977). Como essa infra-estrutura é exclusivamente dedicada ao empreendimento minerador e devido ao próprio isolamento em relação a outras concentrações econômicas e sociais, esse investimento estimula baixos níveis de articulação com outros tipos de investimento. Eses limites podem ser parcialmente modificados por políticas estatais, particularmente como manifesto nos contratos de extração e processamento, mas os Estados exportadores de recursos dependem da tecnologia, das informações técnicas e de mercado, e do acesso aos mercados das empresas e bancos com os quais negociam e, assim, negociam em uma posição relativamente desfavorável. Portanto, a natureza do recurso e de seus mercados determina, em grande parte, os efeitos econômicos e sociais em nível local. Essas limitações físicas, de mercado e tecnológicas restringem as opções econômicas e políticas das sociedades extratoras de recursos. Se os mercados são controlados pelos oligopólios reguladores de preços e de custos, os rendimentos com compensação financeira royalties e impostos para a nação ou região mineradora provavelmente serão baixos, porém estáveis até o esgotamento ou substituição do recurso. A participação de acionistas, levando à capacidade excessiva descoordenada em múltiplas sociedades endividadas, provavelmente estimulará uma extração excessiva ainda maior, desestabilizando mercados e impulsionando ainda mais os níveis de endividamento, além de ampliar o impacto ambiental por unidade de produção. Pelo menos no caso da indústria do alumínio, esses efeitos têm, de fato, ampliado os limites e rigores ambientais na extração mineral.

\section{Algumas parcerias concorrentes}

Vários países latino-americanos começaram a exportar matérias-primas como um meio de captar divisas estrangeiras e de atrair investimentos 
e empréstimos externos diretos. Essa mudança não só inibe a auto-suficiência industrial interna mas também debilita os programas iniciados nos anos 70 para estabelecer suficiente controle sobre os recursos minerais nacionais, a fim de permitir que o Estado estimulasse os efeitos para frente no restante da economia. O nacionalismo otimista da década de 70 em relação aos recursos naturais e sua ênfase na obtenção de linkages (encadeamentos) no país, como também o uso de receitas poupadas para levar adiante a industrialização de substituição da importação, foram substituídos pela confiança na exportação direta de matérias-primas como uma solução para o endividamento e a escassez de capital. No processo, várias empresas e agências de gerenciamento mineral foram desmoralizadas, desviando a competência crescente de gerenciamento autônomo de recursos minerais para a subordinação do planejamento econômico de estratégias a curto prazo, economicamente indefensáveis, baseadas na manipulação de taxas de juros e de câmbio. Freqüentemente, isso envolvia compromissos públicos a longo prazo para a realização de enormes projetos infra-estruturais, cujos custos de juros e de manutenção permaneceram até que os problemas ultrapassassem os ajustes temporários de falta de dinheiro nas contas correntes, que se propunham sanar. Aqui, o Estado sacrifica novamente a credibilidade e os ganhos com programas anteriores, em detrimento de sua própria autonomia e coerência administrativa, pelo acordo fácil de alívio de dívida, que é ineficiente a longo prazo. Como o Estado sucumbe a esse tipo de estratégia, sua posição de negociar com corporações multinacionais (MNCs) e os governos estrangeiros encontra-se progressivamente enfraquecida. O declínio expressivo de mercados minerais no início da década de 80 e as políticas agressivas dos japoneses de alimentar parcerias concorrentes dos mesmos minerais exacerbaram muito essa perda de controle soberano e de política coerente (Bunker, 1989a, 1989b).

A associação entre crise econômica, promoção da exportação de recursos naturais, posição fraca de negociar nos contratos minerais, degradação ambiental e problemas sociais e institucionais é demonstrada amplamente nos atuais programas de extração mineral na Amazônia brasileira. Grandes depósitos de ferro e bauxita, as bases minerais mais amplamente utilizadas e comercializadas na atual economia mundial, foram descobertos no Estado amazônico do Pará na década de 60. Os depósitos de bauxita, localizados relativamente perto do rio navegável Trombetas, foram desenvolvidos com uma rapidez razoável, embora os efeitos para frente em relação à alumina e ao alumínio sofressem uma série de dispendiosas iniciações e falsos reveses. O depósito de minério de ferro de Carajás - o maior do mundo com essa alta qualidade - estava muito mais distante de um porto potencial e foi desenvolvido de forma mais lenta.

Os diferentes modos como esses depósitos eram desenvolvidos refletem em parte as estratégias muito diferentes dos antigos oligopólios e de hegemonias emergentes. No caso do ferro, a US Steel era sócia de um em- 
preendimento localizado perto da boca da mina. Havia um conflito considerável entre a US Steel e seu parceiro brasileiro - uma companhia estatal - no que diz respeito tanto ao tamanho do empreendimento como ao melhor método de exportação. A US Steel queria uma taxa de extração relativamente baixa e planejou usar um sistema de transporte relativamente barato, baseado no transporte fluvial para o porto amazônico de Belém. A Companhia do Vale do Rio Doce (CVRD), a companhia estatal brasileira de mineração, queria construir uma ferrovia para São Luís, um porto oceânico de águas profundas, que permitiria o carregamento em navios suficientemente grandes para competir pelo mercado japonês. A US Steel agia conforme a estratégia de controle oligopólico regional que ela usou tão bem no passado - usando uma quantia moderada de capacidade excessiva controlada para conservar reservas muito grandes - enquanto os brasileiros visavam o mercado japonês, aberto por uma estratégia de transporte muito diferente, que superou os antigos mercados regionais. A CVRD tinha desenvolvido boas relações com os japoneses, vendendo-lhes ferro mediante contratos a longo prazo, intermediados por companhias comerciais japonesas. Além disso, os japoneses participavam ativamente na diversificação da CVRD no transporte mineral marítimo em grande escala.

As reservas de bauxita, descobertas mais ou menos na mesma época, tiveram uma história muito diferente. A ALCAN entrou em uma parceria com a CVRD e vários outros investidores internacionais para explorar as reservas de bauxita, mas sem dúvida o maior efeito na economia nacional e nas economias regionais não veio da própria atividade mineradora mas da iniciativa japonesa de participar de uma fábrica de alumina e alumínio, que seria abastecida por uma grande usina hidrelétrica construída no rio Tocantins. A parceria inicial, proposta por um consórcio de fundidores e fabricantes japoneses de alumínio, bancos e companhias comerciais, era para a construção de um redutor eletrolítico com uma capacidade de 800 mil toneladas por ano, sendo que o joint venture investiria 800 milhões de dólares para a construção da usina. Tanto o governo brasileiro quanto os planejadores industriais japoneses promoveram a usina alegando que a energia adicional gerada estimularia o desenvolvimento industrial na região, inclusive o beneficiamento do alumínio produzido.

Em 1976 e 1977, o governo brasileiro tomou iniciativas importantes para acelerar o desenvolvimento de Carajás e para promover o processamento da alumina e do alumínio oriundos da mina de bauxita de Trombetas. Esse empreendimento requeria muito mais capital que a própria mina de bauxita. A US Steel, sócio no empreendimento de Carajás, foi adquirida em sua totalidade, e a CVRD, a companhia mineradora estatal, começou a buscar outras fontes de capital. As complexas negociações com os membros públicos e privados do consórcio japonês foram concluídas com a decisão de construir uma refinaria de alumina e uma fábrica de alumínio perto de Belém, em Barcarena próximo à confluência do rio Tocantins com a Baía do 
Guamá, parte do complexo formado pelo delta amazônico. Contratos anteriores de venda de minério de ferro para compradores japoneses e alemães, sujeitos a empréstimos públicos e privados, foram decisivos para ensejar o funcionamento de Carajás. Quando os vários bancos de importação e exportação envolvidos - representando os governos norte-americano, japonês, alemão e os da CE - não conseguiram entrar em acordo com a estrutura do pacote de empréstimo, o Banco Mundial convocou uma reunião autorizando seu próprio empréstimo para o projeto, além de coordenar um acordo que proporcionava o financiamento adequado para a implantação do projeto.

A mina de Carajás é a maior no mundo com tão alto teor de minério, e o complexo de alumina e alumínio, conforme planejado originalmente, teria sido também o maior no mundo. A participação japonesa nesses projetos foi prevista com a expectativa de que, a longo prazo, eles teriam efeitos maiores de aumentar as ofertas e manter os preços baixos. A oposição da US Steel e de outros interesses mineradores dos Estados Unidos ao projeto de Carajás - que incluía a pressão do governo do Estado de Minnesota para impedir o empréstimo do Banco Mundial - foi prevista exatamente dentro das mesmas expectativas. As nítidas diferenças entre as ações e atitudes japonesas e norte-americanas manifestam a grande diferença de interesses entre os oligopólios mais antigos, com maior capital de participação concentrado no início da cadeia de produção e com longa experiência em manter a alta dos preços, mediante a limitação da oferta, e a meta da economia em desenvolvimento de diversificar e expandir essa oferta.

Houve, todavia, reações muito diferentes dos antigos oligopólios em relação aos diferentes metais. A U.S. Steel retirou-se do projeto de ferro de Carajás, mas as parcerias que os japoneses conseguiram formar na indústria do alumínio levaram a maioria das firmas a sentir que deveria participar para evitar usurpações ainda maiores em suas parcelas de mercado. Ainda quando se preocupava com uma possível capacidade excessiva resultante dessas estratégias, a ALCOA sentiu-se obrigada a aproveitar-se das mesmas oportunidades que os japoneses criaram e exploraram em suas negociações no que diz respeito à fundição de alumínio na Amazônia (entrevistas do autor com executivos, Pittsburgh, junho, 1990).

O desenvolvimento das minas de Carajás tornou-se ainda mais problemático por causa da crescente evidência de fraqueza dos mercados minerais mundiais, ao final da década de 70 e no início dos anos 80. A U.S. Steel movia-se lentamente, em parte por causa do receio de que a grande capacidade requerida pela escala de investimento baixaria os preços do ferro em nível mundial. Essencialmente, ela não precisava competir consigo mesma num mercado excessivamente abastecido. A CVRD, embora ativamente apoiada pelos ministérios mais relevantes no que diz respeito a seu empreendimento, encontrou numerosos contratempos em sua busca de investidores diretos. Ela ainda prosseguiu com o desenvolvimento de uma mina piloto e com a construção de uma ferrovia até a costa - a parte principal do investi- 
mento - com empréstimos do Banco Nacional de Desenvolvimento Econômico e Social (BNDES) e com a venda de ações e debêntures. Numa tentativa de fazer a empresa mais atraente tanto para os investidores domésticos e internacionais quanto para as instituições financeiras de empréstimo, o Ministro do Planejamento, Delfim Netto, instituiu uma autoridade em desenvolvimento regional na área a ser aberta pela ferrovia e concedeu generosos incentivos fiscais baseados em isenções ou reduções de impostos tendo em vista os lucros obtidos naquela área. O Estado, esforçando-se para obter divisas, e já excessivamente comprometido num grande projeto mineral que demandava um significativo endividamento, ampliou ainda mais sua exposição política e econômica ao estabelecer esse projeto de desenvolvimento regional ambicioso, mas também extremamente imperfeito (Bunker, 1989a; Hall, 1990). A usina proposta estava localizada dentro da área designada pelo programa e, dessa maneira, gozava de alguns de seus incentivos, aumentando assim a responsabilidade do Estado nacional em relação a seus custos com a infra-estrutura. As parcerias na indústria de alumina e de alumínio, tal como o projeto de mineração de Carajás, obedeciam às estratégias legítimas para alcançar a auto-suficiência nacional no que diz respeito a metais não-ferrosos, mas a forma dos projetos e seus efeitos políticos e sociais a longo prazo, em última instância, resultaram muito mais na crise financeira externa do Brasil e na crise de legitimidade interna do regime militar do que na racionalidade empresarial. De Sá (1994) afirma que o desejo ambicioso, endividante, além de ambientalmente destrutivo e demograficamente desestabilizante do Brasil que queria tornar-se um exportador importante de alumínio, foi motivado mais por considerações em relação à dívida externa e ao déficit público do que pelo planejamento econômico. Acreditamos que seria mais correto dizer que um programa coerente para alcançar a auto-suficiência numa indústria expansiva de metais nãoferrosos foi substituído por políticas que visavam a manutenção da legitimidade e a obtenção de divisas, necessárias para manter poder e estabilidade política a curto prazo, durante crises econômicas.

A posição negociadora dos brasileiros em relação aos investidores estrangeiros diretos e às agências financiadores era diretamente condicionada por sua perigosa situação fiscal. A CVRD e o Estado brasileiro estavam sujeitos tanto à dependência tecnológica quanto ao poder de mercado dos japoneses, mas suas margens de negociação eram diretamente limitadas pela necessidade geral de capital estrangeiro e pela legitimidade conferida a grandes projetos. O mais importante é que as condições declinantes do comércio e os mercados decadentes para todos os países exportadores de minerais fizeram os exportadores do Terceiro Mundo - dependentes da exportação - desastrosamente competitivos uns com os outros.

Durante a década de 70, os japoneses procuravam fazer parcerias para a transformação (redução eletrolítica) de alumínio com vários outros países, inclusive a Indonésia, a Austrália, a Venezuela e o Canadá. Eles utiliza- 
vam sua posição para jogar os diferentes países ricos em bauxita uns contra os outros e, crescentemente, usaram a capacidade excessiva - criada para reduzir seus próprios investimentos e para aumentar os dos países mineradores - na economia mundial. Esse jogo era particularmente caro para os países exportadores de matéria-prima, porque grande parte do custo do alumínio está no desenvolvimento da força hidrelétrica, ou tem estado desde a alta dos preços de petróleo nos anos 70. Essas parcerias foram projetadas, num sentido muito real, para exportar energia elétrica tanto quanto bauxita. Os japoneses foram capazes de explorar o nacionalismo em relação aos recursos naturais dos países ricos em bauxita com potencial hidrelétrico, ao enfatizar a promessa de que a disponibilidade de eletricidade barata atrairia outras indústrias, inclusive fábricas que transformariam o alumínio primário em outras mercadorias. Desse modo, o Estado nacional foi induzido não simplesmente a fornecer a infra-estrutura de energia e de transporte para as usinas de alumínio, mas a fazer isto com pré-contratos, com preços de energia que somente seriam viáveis na hipótese de múltiplos usuários industriais associados. No caso brasileiro, no que diz respeito à parceria com a ALBRAS - composta pela CVRD e por um consórcio japonês -, a expectativa era de contribuir substancialmente para a construção de Tucuruí, a hidrelétrica que forneceria eletricidade à usina de alumínio. O Ministro das Minas e Energia criou a "lei de participação", em 1973, especificamente para permitir o investimento estrangeiro em energia elétrica para os maiores consumidores. Em 1974, numa das sessões de negociação entre a CVRD e o consórcio japonês, os japoneses anunciaram a inviabilidade do projeto da usina de alumínio, caso eles tivessem de investir na hidrelétrica. Os sócios recuaram, não somente em relação ao investimento na hidrelétrica, mas também exigiram, e conseguiram (a) um preço máximo para a eletricidade, vinculado ao preço de alumínio, (b) uma cidade para os operários, financiada com dinheiro público, e (c) um porto também construído com dinheiro público. A parceria entre as usinas Alcoa e Billiton, no Maranhão, foi capaz de conseguir condições quase igualmente favoráveis para sua eletricidade. Os pareceres dos Ministérios da Fazenda e do Planejamento, segundo os quais a nova posição japonesa significava que o projeto já não era mais viável para o Brasil, foram contestados pelo Ministro das Minas e Energia, que alegava que o governo já_estava tão comprometido em relação à realização do projeto que não podia mais se retirar sem perder credibilidade. Mesmo dentro da CVRD, existia uma resistência significativa à realização do projeto. O governo Geisel simplesmente prosseguiu com o projeto, que na realidade deveria ter sido arquivado por todos os critérios econômicos, desde 1976. Os japoneses insistiram depois em reduzir a fábrica da ALBRAS para menos da metade da capacidade inicialmente planejada, de 800 para 640 e depois para 320 mil toneladas por ano. Eles também interromperam o desenvolvimento da refinaria de alumina associada, alegando que o preço da alumina era tão baixo que era mais econômico importá-la 
do Suriname e da Venezuela (uma parte da alumina desses países era feita da bauxita oriunda de Trombetas) do que refinar a bauxita do próprio Trombetas. Assim, uma das justificativas principais para o enorme dispêndio público em usinas hidrelétricas, linhas de transmissão, estradas e uma cidade planejada - a integração da mineração e do processamento da bauxita do Trombetas em nível nacional - simplesmente não aconteceu.

Ficou claro que os japoneses não tinham nenhum interesse particular em processar bauxita ou alumina e que seus interesses eram mais diretamente voltados para o alumínio primário. Eles usaram e manipularam de forma hábil a aspiração brasileira de uma maior integração a partir da mina, mas de fato não tinham nenhum compromisso em relação a isso. A CVRD foi capaz de jogar em ambos os lados da cerca, proclamando que ela não podia agir contra os interesses de seu parceiro japonês mesmo quando lamentava publicamente que não estava atingindo a integração vertical, enquanto, de fato, usava sua associação com os japoneses para justificar suas estratégias de maximização de lucro, em vez de promover a política do Estado para a integração nacional.

Dada a complexidade e a diversidade dos consórcios e dos acordos de financiamento que mantinham as diferentes parcerias na indústria do alumínio em vários países e dadas as incertezas dos mercados minerais, seria ultrapassar os limites da credulidade sugerir que as estratégias japonesas fossem concebidas como uma totalidade integrada na obtenção de alumínio. Tal dedução é, de qualquer forma, necessária para a discussão deste artigo. Está fora de questão o fato de que existiam negociações claras e contínuas entre o Estado e as empresas, que a intenção geral dessas negociações era assegurar o acesso às fontes de matérias-primas confiáveis e baratas e que os japoneses tentaram induzir os governos dos países ricos em matérias-primas a participar de parcerias. As entrevistas com funcionários da CVRD e do governo brasileiro indicam, também, que as parcerias eram negociadas umas contra as outras, com a ameaça de que os japoneses poderiam simplesmente expandir uma das parcerias, caso as condições das outras não fossem suficientemente favoráveis. A redução progressiva na escala da ALBRAS, embora justificável em termos de mercados variáveis, sugere que os japoneses estavam manipulando as aspirações brasileiras para conseguir que estes garantissem os custos com a infra-estrutura. Ainda mais conclusivo é o fato de que a escala da primeira proposta japonesa para uma usina de 800 mil toneladas por ano era duas vezes maior do que a escala ideal aceita para uma usina, naquela época. A fábrica proposta estava, evidentemente, dimensionada para justificar os custos públicos com a usina hidrelétrica.

A Eletronorte, a companhia estatal de energia elétrica criada para construir Tucuruí, acabou assumindo enormes dívidas e comprometeu-se a vender sua eletricidade a preços bem abaixo dos custos de geração e financeiros. A usina propriamente dita, construída e fechada às pressas quando os protes- 
tos contra ela e seus altos custos começaram a surgir, está sendo corroída pela vegetação tropical apodrecida, que por sua vez destrói as fontes de pesca e de água (os recursos hídricos), além de criar sérios problemas de saúde para as comunidades rio abaixo. A reprodução de peixes aumentou muito atrás da usina, mas alguns especialistas alegam que se trata de um fenômeno temporário. Muitos moradores, cujas terras foram desapropriadas por causa da usina, não foram adequadamente compensados ou transferidos (Hall, 1990). Devido às ineficiências nas linhas de transmissão - construídas primordialmente para servir à fábrica de alumínio, mas exigidas cada vez mais para suprir a demanda crescente de eletricidade e para superar a capacidade reduzida dos sistemas hidrelétricas no Nordeste, arrasados pela seca ou obstruídos por resíduos -, a Eletronorte e o sistema nacional do qual ela faz parte não só falharam em fornecer toda a eletricidade demandada à fundição no Maranhão, mas tiveram que aumentar seus preços para outros usuários, inclusive para os usuários urbanos e as instituições públicas. As companhias elétricas estão tão endividadas que não conseguem fazer empréstimos para construir novas linhas de transmissão ou mesmo para manter as linhas existentes, e, assim, vários setores da economia enfrentam agora a falta de eletricidade. Os efeitos no emprego e na saúde de um fornecimento elétrico incerto podem ser devastadores. A ALBRAS está pressionando a Eletronorte a terminar uma segunda linha de transmissão para a segurança ou o auxílio em relação à usina de alumínio. A Eletronorte não receberia nenhuma renda adicional por esse investimento essencial e, portanto, estaria pouco disposta a ir em frente. Além disso, os sócios japoneses alegavam a desobediência do Brasil em relação às propostas do FMI e negavam-se a conceder empréstimos para o projeto. As linhas de transmissão - em péssimas condições - desmoronaram em março de 1992, o que resultou em altos custos de conserto e em falta de energia. As perdas foram estimadas em mais de US\$ 100 milhões.

Por uma série de razões que têm a ver com a escala, com os incentivos à exportação, com as diferenças entre o preço da exportação e o preço doméstico do alumínio e com as leis tributárias, a ALBRAS tem-se mostrado relutante em vender alumínio no mercado local. O parque industrial, criado às custas do Estado para atrair indústrias no final da cadeia produtiva a partir da usina de alumínio - uma das justificativas dos dispêndios públicos no porto - está vazio. As recentes tentativas do Estado local para recuperar alguns dos ônus sobre as finanças públicas, por meio de impostos, estão sendo desafiadas por batalhas legislativas complexas e técnicas que tratam da composição química do alumínio - essencialmente uma discussão para definir quando o alumínio é industrializado e, desse modo, isento de impostos quando exportado, ou quando é simplesmente semiacabado e, assim, sujeito a impostos. Também aqui, a CVRD pode invocar a necessidade de convencer os japoneses a manter sua participação a fim de terminar a construção da fábrica de alumínio (finalmente concluída em 1991) e talvez terminar a refinaria de alumina abandonada. Se forem cobrados 
impostos, funciona o conhecido raciocínio: os sócios da parceria investirão em outro lugar.

Os japoneses empregaram variantes dessa estratégia na Indonésia e na Venezuela, adaptando-as às condições e aspirações políticas locais. Depois jogaram cada nação rica em matéria-prima uma contra a outra, quando exigiram, e conseguiram em relação à proposta original, (a) maior participação acionária e encargo da dívida por parte dos governos locais, (b) preços mais baixos para a energia e (c) que uma parte bem maior do investimento total fosse assumida pelos governos e definida como pública. Esses governos participaram, assim, diretamente na criação da capacidade excessiva que baixou o preço de suas exportações. Também justificaram a redução do tamanho dos projetos, que havia sido utilizado para justificar, em princípio, o enorme dispêndio público. Tucuruí ainda tem geradores para menos da metade da eletricidade planejada e pode transmitir somente menos do que a metade de sua capacidade de geração, mas o tamanho da usina, a quantidade de terra perdida e o número de pessoas deslocadas são tão grandes quanto os planos iniciais. Os Estados locais e o nacional tiveram que assumir enormes custos públicos e sociais para um retorno bem menor do que o originalmente proposto. Além disso, permanecem altamente suscetíveis a novas ofertas que dizem respeito à expansão da capacidade, pois estão desesperados para pagar essa infraestrutura. Esta é a nova forma de capacidade excessiva, atingida de forma muito barata pelos japoneses.

Alguns dos problemas causados por esse projeto, em particular, são comuns a certos tipos de extração de recursos dificilmente podem ser atribuídos diretamente à crise econômica nacional. Alguns membros da CVRD e de diferentes ministérios estavam fortemente comprometidos com o desenvolvimento de uma indústria nacional auto-suficiente de alumínio. Os problemas existem, mas o governo brasileiro estava tão ansioso para captar divisas estrangeiras que jamais conseguiu exercer sua opção de desistência, que era parte das negociações, e, portanto, tomou uma série de decisões empresariais com conseqüências econômicas e sociais nocivas. Por outro lado, o consentimento quase total dos brasileiros em relação às exigências e aos cortes dos japoneses deveu-se à crise, economicamente estabelecida, de legitimidade estatal e a percepção da necessidade de divisas.

A construção das usinas hidrelétricas planejadas na Amazônia estimulou o protesto organizado de grupos indígenas e de camponeses. Esses grupos aprenderam cada vez mais sobre como formar alianças com ambientalistas nacionais e internacionais. A Eletronorte está cercada por todos os lados. A ALBRAS parece operar como uma fábrica modelo, mas somente é capaz de fazer isso devido aos contratos, que passaram a maioria dos custos operacionais para o setor público, inclusive para a Eletronorte.

A posição negociadora do Estado brasileiro foi gravemente enfraquecida devido à sua vontade de participar em empreendimentos cujo viabilida- 
de econômica foi progressivamente desgastada em favor do sócio estrangeiro, pois as várias crises econômicas limitam as alternativas econômicas e políticas do Estado. A ironia da existência de Tucuruí - apresentada como um importante feito nacional, enquanto perde dinheiro e enquanto o setor de alumínio consome quase 7 \% de um fornecimento elétrico nacional crescentemente insuficiente (De Sá, 1994) - reflete até que ponto o governo brasileiro foi levado a alegar que seus desastres eram triunfos, enquanto a economia que os legitimou desabava. A ALBRAS apresenta um lucro pequeno, mas isso só por causa das enormes perdas e dos juros acumulados com a usina e o porto, que pesam sobre as contas públicas. A energia pode representar até $20 \%$ da dívida de \$120 bilhões do Brasil.

\section{O Japão e as novas formas de investimento na hierarquia inconstante da economia mundial}

Charles Oman $(1984,1989)$ escreveu de maneira contundente que "novas formas de investimento", definidas como investimentos internacionais, nos quais os investidores estrangeiros não têm interesse pelo controle acionário, tiveram um papel crescentemente importante nas relações entre economias desenvolvidas e subdesenvolvidas, desde o início dos anos 70 (1984: 12). Oman descreve amplamente a NFI como "o conjunto de métodos pelos quais uma companhia estrangeira é capaz de empreender e até, em certos casos, de estimular a criação de capacidade de produção num país hospedeiro, sem ter de contar com a propriedade acionária para afirmar o controle parcial ou total sobre o projeto de investimento. Na indústria mineradora, a NFI se tornou substancialmente dominante durante os anos 70" (Bomsel et. al., 1990: 11). Dois terços (2/3) dos principais projetos de metais básicos (ferro, cobre e alumínio) empreendidos desde o início da década de 70 contaram com a NFI (Oman, 1989; Bomsel et. al., 1990: 17). Oman e seus associados vêem a NFI como o resultado do mercado variável e das condições financeiras, junto com o aumento do envolvimento de Estados nacionais nos países subdesenvolvidos. Eles reconhecem que, proporcionalmente, a NFI teve um impacto muito maior no setor extrativo, mas eles tendem a menosprezar esse setor por causa da reduzida taxa de investimento durante a crise dos mercados minerais nas décadas de 70 e 80. Eles também limitam sua perspectiva em relação a questões de arrendamento, de competição entre empresas e barreiras variáveis de entrada (Bomsel et. al., 1990: 14). Esses fatores refletem a conjuntura de demanda de mercado e de custos de capital em determinadas épocas, mas ignoram a estrutura variável da economia mundial as estratégias nacionais que levam às mudanças na hierarquia do sistema mundial, e os limites naturais, econômicos e políticos peculiares nas economias extrativas. Conseqüentemente, eles consideram as dificuldades dos exportadores de matérias-primas conjunturais em vez de estruturais, conforme declarações como: 
"A exportação de matérias-primas e, portanto, a exploração de uma vantagem comparativa natural, não garante mais uma transferência líquida de recursos do mundo externo para o país hospedeiro. A desestabilização dos mercados de matérias-primas fez com que os benefícios financeiros, esperados com a exploração de recursos naturais, ficassem muito incertos. Os recursos naturais não podem mais ser considerados um tesouro enterrado" (Bomsel et. al., 1990: 16).

Argumentaríamos, ao contrário (Bunker, 1985, 1989a), que a extração de recursos naturais sujeita as economias regionais a uma série de desvantagens que emergem (1) da rigidez da localização, (2) da dependência em relação aos mercados e tecnologias externas e (3) do imperativo do capital industrial de reduzir os custos de matérias-primas. A NFI é simplesmente a mais recente de uma série de estratégias historicamente condicionadas, pelas quais empresas capitalistas e nações industriais garantem fontes baratas e seguras de matérias-primas. Essas estratégias variam conforme as condições técnicas, políticas e financeiras da economia mundial. Entretanto, por seguirem as iniciativas dos países industrializados - de onde a demanda do consumidor e a disponibilidade de crédito emergem e onde a informação técnica, de produção e de mercado é concentrada -, tendem a redundar em desvantagem para os países exportadores de recursos, embora o grau de desvantagem varie com o tempo e com a própria matériaprima. A NFI é mais bem vista como um reflexo da competição entre países centrais, tanto entre empresas quanto entre economias nacionais e, particularmente, como o resultado das estratégias japonesas para explorar as fraquezas e oportunidades na conjuntura da economia mundial, à medida que ascenderam para a hegemonia industrial.

Isso não significa dizer que as estratégias japonesas são suficientes para explicar os mercados minerais, as estruturas de financiamento e as conseqüências ambientais e econômicas dos grandes projetos minerais durante as décadas de 70 e 80, quando suas estratégias - sensíveis à estrutura e à conjuntura da economia mundial - catalisaram mudanças na competição entre empresas e Estados de tal forma que houve uma reação às mudanças no setor de minerais e nos mercados financeiros mundiais, o que provocou mudanças naqueles setores e mercados. Os japoneses não alimentaram o nacionalismo em relação aos recursos naturais e as aspirações pelos efeitos para frente, mas efetivamente manipularam essa situação em um contexto de crédito fácil, de forma que lhes fosse permitido produzir uma capacidade excessiva, enquanto participavam de forma mínima nos riscos envolvidos.

Os esforços japoneses para obter acesso direto às matérias-primas não visavam necessariamente a produção de capacidade excessiva, mas levaram, inevitavelmente, a isso. A predisposição de países mineradores para participar nos custos de investimento e para assumir a maioria ou todos os custos de infra-estrutura criou uma condição que os japoneses podiam ex- 
plorar, mas outras nações e empresas sentiram, posteriormente, que também tinham que explorá-la a fim de não perder sua parte do mercado. Uma vez que as estratégias japonesas se tornaram operacionais, outras empresas foram forçadas a usar a NFI, ainda que tivessem muito mais motivos para temer o desenvolvimento da capacidade excessiva. Desse modo, os membros dos oligopólios minerais foram forçados a acelerar o fim de seu antigo sistema de controle de mercado.

Os japoneses tinham diversas vantagens com o sistema que eles estavam criando. A NFI, produzindo capacidade excedente com poucos riscos para o investidor estrangeiro, baixou efetivamente o custo das matériasprimas. Isso favorece as companhias com menor integração no início da cadeia produtiva e com menor exposição financeira em relação aos próprios bens primários. As companhias com propriedade total ou maior, que dominaram as formas mais antigas de IDE, eram, portanto, muito menos capazes de usar a NFI em seu próprio benefício, pois estavam muito mais sujeitas a perdas com os custos reduzidos das matérias-primas. A NFI estimulou um movimento para o lucro no final da cadeia de produção, mas as companhias com níveis de integração no início da cadeia produtiva eram muito menos ágeis para fazer essas mudanças. A agilidade japonesa foi exaltada também pela deliberada coordenação entre os setores privados e o Estado. Várias agências estatais e associações empresariais agiram para solucionar as tensões e contradições em estratégias que dependiam da ação colaboradora por parte das empresas e bancos, cujos maiores lucros emergiam de pontos bem diversos da cadeia de produção. As parcerias que produziam a capacidade excessiva necessariamente reduziram ou eliminaram os lucros e eram ameaçadas com prejuízos devido ao investimento no início da cadeia produtiva. Oman (1984: 83) cita o argumento de Ozawa (1979) segundo o qual 80 \% dos investimentos estrangeiros do Japão nas indústrias extrativas, que operam com a maior parte ou com uma participação de 100 \%, não são lucrativos como empreendimentos individuais, sendo seu objetivo primário uma fonte segura de oferta. Oman considera que a disposição japonesa em usar a NFI em indústrias extrativas depende da relação entre os setores privados e públicos para fornecer "os fundamentos a empresas a fim de empreender parcerias em que benefícios sociais como o acesso seguro às matérias-primas para a economia doméstica, excedem os benefícios privados de projetos de investimento individual ou mesmo de investidores individuais". Embora cite Ozawa (1979: 34-35) acerca da importância de subsídios do governo para as empresas japonesas em parcerias de mineração, Oman não leva totalmente em conta até que ponto o Estado japonês, por meio de empréstimos diretos, créditos e taxas de juros reduzidas, tem ajustado sua própria contribuição em parcerias como as da ALBRAS e da Asahan a fim de manter os incentivos que essas parcerias proporcionavam aos investidores corporativos, quando os efeitos de capacidade excessiva prevista ameaçaram reduzir os rendimentos de cada projeto. 
A íntima articulação entre consumidores e produtores, no Japão, tanto por meio do MITI, quanto por meio do Keidanren, significava que os consumidores conseguiam fazer exigências às companhias mineradoras de forma mais efetiva do que nos Estados Unidos. Apesar disso, em ambos os casos, havia pressões dos consumidores para fornecer créditos e tecnologias que permitissem a participação dos países hospedeiros nos custos dos projetos minerais. Conforme as companhias mais dinâmicas transferiam seus lucros para o final da cadeia produtiva, surgiam maiores benefícios a serem obtidos pelo aumento dos custos dessas tecnologias para os parceiros hospedeiros, um fator que exacerbava os custos crescentes do desenvolvimento de novos projetos e, portanto, aumentava ainda mais a tendência para a NFI. Quando os custos de capital subiram e os preços das matérias-primas caíram, aumentou a pressão sobre os membros do oligopólio em desintegração para que seguissem as estratégias da NFI em vez daquelas do IDE. Aumentou também a probabilidade de crescimento da dívida e de redução dos rendimentos para os países hospedeiros.

A participação em parcerias aumenta a exposição do país minerador ao risco e à dívida, ao passo que reduz a capacidade do Estado para a regulamentação desfavorável ao investidor estrangeiro. Essa conseqüência é particularmente significativa à luz das alegações de alguns analistas, que afirmam que as parcerias se tornaram atraentes para as companhias mineradoras multinacionais, e financiá-las tornou-se atraente para os bancos internacionais, em resposta à possível ameaça de nacionalização e à regulamentação desfavorável que emergiram das medidas mais intervencionistas dos Estados mineradores no mundo inteiro, durante as décadas de 60 e 70 (Mikesell, 1979; Bosson e Varon, 1977; vide também Oman 1984; 71-74 sobre a hipótese de "reação defensiva"). O nacionalismo em relação aos recursos naturais era, de fato, algo ameaçador para o antigo sistema de controle oligopólico, mas as beneficiárias das mudanças resultantes foram as hegemonias emergentes no centro industrial e não os exportadores de minerais na periferia. Paradoxalmente, o nacionalismo em relação aos recursos tornou-se uma alavanca que os japoneses utilizaram para induzir os Estados periféricos a assumir os custos de novas estratégias de acesso dos japoneses.

A incapacidade dos Estados ricos em recursos naturais de aumentar seus benefícios reside em grande parte (a) na natureza dos empreendimentos de extração mineral, (b) na sua subordinação em relação às características físicas e de mercado das matérias-primas que exportam, (c) na sua vulnerabilidade para a substituição - técnica e/ou geográfica - em face da exaustão, dos custos crescentes, das tentativas de intervenção estatal e da peculiar rigidez espacial e fiscal, impostas às suas economias regionais (Bunker, 1989a). Reflete também uma maior flexibilidade das economias centrais para explorar a competição entre parceiros comerciais menos desenvolvidos e para manipular as condições comerciais, os pontos de 
lucro e o acesso a créditos e divisas. Moran (1974), Bosson e Varon (1977), Girvan (1979) e Becker (1983) prenunciaram uma capacidade crescente dos governos dos países exportadores de matérias-primas de se beneficiarem, não somente com a negociação, que Moran mostrou ser obsoleta em relação à vantagem transferida do investidor multinacional para o país minerador, durante as negociações originais, depois da determinação do investimento maior e fixo, mas também com o entendimento crescente dos funcionários locais, à medida que aprendem mais sobre tecnologia e mercados. O otimismo inicial foi desmentido pela facilidade com que empresas e Estados do centro - particularmente aqueles menos embaraçados pelas formas anteriores de domínio - transformaram a ameaça de controle local num meio vantajoso de participação de risco.

O domínio na indústria de minerais mudou, mas as nações exportadoras têm suportado o custo dessa mudança sem receber muitos dos seus benefícios. O fornecimento de matérias-primas permanece essencial para o crescimento industrial; a participação nos riscos de extração e de processamento primário permitiu às firmas em ascensão assegurar uma oferta barata e ininterrupta de matérias-primas enquanto transferiam seus próprios lucros para o final da cadeia de produção (Oman, 1984: 45). Os mercados de minerais tornaram-se mais e mais instáveis à medida que as nações exportadoras - descoordenadas e endividadas - participavam de parcerias mineradoras competitivas entre si. 


\section{Referências bibliográficas}

ALBION, Robert G. Forests and Sea Power. The Timber Problem of the Royal Navy. 1952-1862. Cambridge: Harvard University Press, 1926.

BAIROCH, Paul. Historical Roots of Economic Underdevelopment: Myths and Realities. In: WOLFGANG J. Mommsen; OSTERHAMMEL, Jurgen (Ed.). Imperialism after Empire: Continuities and Discontinuities. London: Allen and Unwin, 1986. p. 191-216.

BECKER, David. The New Bourgeoisie and the Limits of Dependency. Princeton: Princeton University Press, 1983.

BOMSEL, Olivier et al. Mining and Metallurgy Investment in the Third World: The End of Large Projects. Paris: OECD, 1990.

BOSSON, R.; VARON, B. The Mining Industry in the Third World. Washington. D.C.: World Bank, 1977.

BROCKWAY, Lucile. Science and Colonial Expansion: The Role of the British Royal Botanical Gardens. New York: Academic Press, 1979.

BUNKER, Stephen G. Underdeveloping the Amazon: Extraction, Unequal Exchange and the Failure of the Modern State. Champaign: University of Illinois Press, 1985.

BUNKER, Stephen G. Staples, Links, and Poles in the Construction of Regional development theories. Sociological Forum 4, n. 4, p. 589-609, 1989a.

BUNKER, Stephen G. The Eternal Conquest. NCLA report on the Americas 23, n. 1, p. 27-40, 1989b.

BUNKER, Stephen G.; O'HEARN, Denis. Strategies of Economic Ascendants for Access to Raw Materials: A Comparison of the U.S. and Japan. In: RAVI, Arvind Palat (Ed.). Pacific Asia and the future of the World System .Westport. Conn.: Greenwood Press, 1992. p. 83-102.

CARDOSO, Fernando Henrique; FALETO, Enzo. Dependency and Development in Latin America. Berkeley: University of California Press, 1979.

CHASE-DUNN, Christopher. Global Formations: Structures of the World-Economy. New York: Brasil Blackwell, 1989

GIRVAN, Nornan. Economic Nationalism vs. Multinational Corporatiens: Revolutionary or evolutionary Change? In: SKLAR, H. (Ed.). Trilateralism: The Trilateral Commission and Elite Planning for World Management. Boston: South End Press, 1980. p. 437-467.

HALL, Anthony. Developing Amazônia: Deforestation and Social Conflict in Brasil's Carajás Programme. Manchester: Manchester University Press, 1990.

HARVEY, David. The Limits to Capital. Chicago: University of Chicago Press, 1982.

HOBSBAWM, Eric. Industry and Empire. Harmondsworth: Penguin Books, 1968. 
INNIS, Harold A. Problems in Canadian Economic History. Toronto: University of Toronto Press, 1956.

KEOHANE, Robert O. After Hegemony. Cooperation and Discord in the World Political Economy. Princeton: Princeton University Press, 1984.

KRASNER, Stepen. Defending the National Interest: Raw Materials Investments and U.S Foreign Policy. Princeton: Princeton University Press, 1978.

LENIN, V. I. Imperialism: The Highest Stage of Capitalism. New York: International Publishers, 1939.

MARX, Karl. Capital: A Critique of Political Economy. Vol. 3. New York: International Publishers, 1967.

McMICHAEL, Philip. Settlers and the Agrarian Question: Foundations of Capitalism in Colonial Australia. Cambridge: Cambridge University Press, 1984.

MEZGER, Dorothea. Copper in the World Economy. New York: Monthly Review Press, 1980.

MIKESELL, Raymond. The World Copper Industry. Structure and Economic analysis. Baltimore: Johns Hopkins University Press for Resources for the Future, 1979.

MORAN, T. H. Multinational Corporations and the Politics of Dependency. Copper in Chile. Princeton: Princeton University Press, 1974.

MORAN, T. H. Managing an Oligopoly of Would-be Sovereigns: The Dynamics of Joint Control and Self-Control in the International Oil Industry Past. Present and future. International Organization, 41, n. 4, p.574607, 1987.

NANKANI, Gobind. Development Problems of Mineral-Exporting countries. World Bank Staff Working Papers, n. 354, 1979. Mimeo.

OMAN, Charles. New Forms of Investment in Developing Countries. Paris: OECD, 1984

OMAN, Charles. New Forms of Investment in Developing Country Industries: Mining. Petrochemicals. Automobiles. Textiles. Food. Paris: OECD, 1989.

OZAWA, T. Multinationals. Japanese Style: The Political Economy of Outward Dependency. Princeton: Princeton University Press, 1979.

OZAWA, T. Japan's 'Revealed Preference' for the New Forms of Investment: A Stock-taking Assessment. In: OMAN, C.(Ed.) New Forms of International Investiment. The National Perspective. Paris: OECD Development Center Papers, 1984, p. 22-41.

RADETZKI, Marian. Changing Structures in the Financing of the Mineral Industries in the LDCs. Development and Change, II, n. 1, 1980, p.1-15.

VERNON, Raymond. Two Hungry Giants: The United States and Japan in the Quest for Oil and Ores. Cambridge: Harvard University Press, 1983.

FRIEDMAMM, H. F. Distance amd Duradiliy: shaky Foumdatiomf Ofadthe World Food Economy. Third World Quarterly, 13, n. 2, 1992. p. 37-83. 